\title{
Quarterly Report on the Ferrocyanide Safety Program for the Period Ending June 30, 1996
}

\author{
G. T. Dukelow \\ R. J. Cash \\ J. E. Meacham
}

Date Published

July 1996

Prepared for the U.S. Department of Energy

Assistant Secretary for Environmental Management

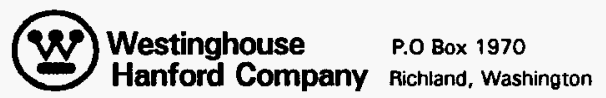

Management and Operations Contractor for the

U.S. Department of Energy under Contrect DE-AC06-87RL10930 


\section{RELEASE AUTHORIZATION}

\section{Document Number: WHC-EP-0474-21}

Document Title: Quarterly Report on the Ferrocyanide Safety Program for the Period Ending June 30, 1996

Release Date: $\quad 7 / 31 / 96$

This document was reviewed following the procedures described in WHC-CM-3-4 and is:

\section{APPROVED FOR PUBLIC RELEASE}

WHC Information Release Administration Specialist:

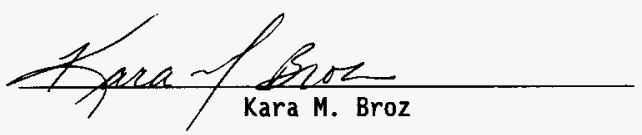

July 31,1996 


\title{
QUARTERLY REPORT ON THE FERROCYANIDE SAFETY PROGRAM FOR THE PERIOD ENDING JUNE 30, 1996
}

\author{
G. T. Dukelow \\ R. J. Cash \\ J. E. Meacham
}

\begin{abstract}
This is the twenty-first quarterly report on the progress of activities addressing the Ferrocyanide Safety Issue associated with Hanford Site high-level radioactive waste tanks. Progress in the Ferrocyanide Safety Program is reviewed, including work addressing the six parts of Defense Nuclear Facilities Safety Board Recommendation 90-7 (FR 1990). All work activities are described in the revised program plan (DOE 1994b), and this report follows the same format presented there. A summary of the key events occurring this quarter is presented in Section 1.2. More detailed discussions of progress are located in Sections 2.0 through 4.0.
\end{abstract}


WHC-EP-0474-21

This page intentionally left blank. 


\section{CONTENTS}

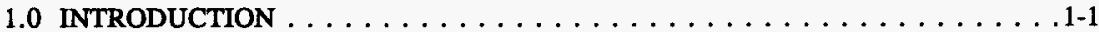

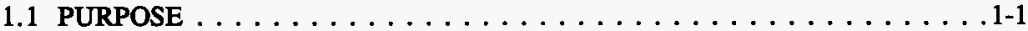

1.2 QUARTERLY HIGHLIGHTS $\ldots \ldots \ldots \ldots \ldots \ldots \ldots \ldots \ldots \ldots \ldots$

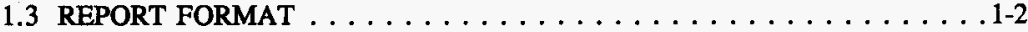

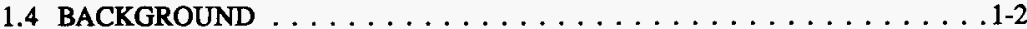

2.0 FERROCYANIDE SAFETY DOCUMENTATION $\ldots \ldots \ldots \ldots \ldots$. . . . . .

3.0 ACTIONS TO COMPLETE DNFSB RECOMMENDATION 90-7 . . . . . . . 3-1

3.1 ENHANCED TEMPERATURE MEASUREMENT $\ldots \ldots \ldots \ldots \ldots$. . . .

3.1.1 Instrument Trees . . . . . . . . . . . . . . . . 3-1

3.1.2 Upgrades to Existing Temperature Monitoring Instrumentation . . . . 3-2

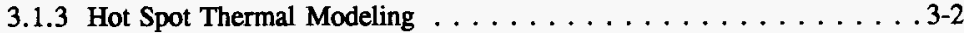

3.1.4 Infrared Scanning System . . . . . . . . . . . . . . 3-3

3.1.5 Cooling System Requirements . . . . . . . . . . . 3-3

3.2 CONTINUOUS TEMPERATURE MONITORING $\ldots \ldots \ldots \ldots \ldots \ldots$ 3-4

3.3 COVER GAS MONITORING $\ldots \ldots \ldots \ldots \ldots \ldots \ldots \ldots \ldots \ldots \ldots$

3.3.1 Interim Flammable Gas Monitoring . . . . . . . . . . . 3-5

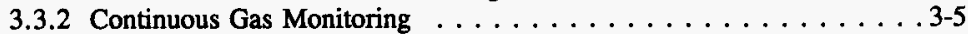

3.4 FERROCYANIDE WASTE CHARACTERIZATION $\ldots \ldots \ldots \ldots \ldots \ldots$. . $\ldots$

3.4.1 Ferrocyanide Tank Waste Sampling and Analyses . . . . . . . . 3-7

3.4.2 Estimation of Water Content . . . . . . . . . . . 3-10

3.4.3 Moisture Retention Properties of Ferrocyanide

Sludge and Saltcake Simulants . . . . . . . . . . . . 3-13

3.5 CHEMICAL REACTION STUDIES . . . . . . . . . . . . . . 3-14

3.5.1 Chemical Reaction Studies at Pacific Northwest National Laboratory 3-14

3.5.2 Preparation and Characterization of Ferrocyanide Simulants . . . . 3-18

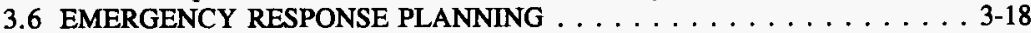

4.0 IMPLEMENTATION OF THE WYDEN AMENDMENT $\ldots \ldots \ldots \ldots \ldots \ldots$. . . .

4.1 THE WATCH LIST $\ldots \ldots \ldots \ldots \ldots \ldots \ldots \ldots \ldots . \ldots \ldots$. . . . . . . . . .

4.2 TEMPERATURE MONITORING $\ldots \ldots \ldots \ldots \ldots \ldots \ldots \ldots \ldots \ldots$

4.3 PRESSURE MONITORING $\ldots \ldots \ldots \ldots \ldots \ldots \ldots \ldots \ldots$

5.0 PROGRAM SCHEDULES AND MILESTONES $\ldots \ldots \ldots \ldots \ldots \ldots \ldots$. $\ldots \ldots$

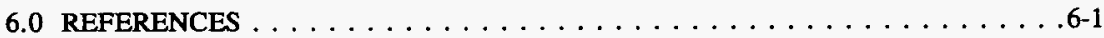

APPENDIX

A FERROCYANIDE TANK INFORMATION SUMMARY $\ldots \ldots \ldots \ldots \ldots$ A-1 


\section{LIST OF FIGURES}

3-1 Ammonia Production and Reproducibility in the Hydrolysis of In-Farm-1B Simulant in $25 \mathrm{~mL}$ of $2 \mathrm{M} \mathrm{NaOH}$ at $90^{\circ} \mathrm{C}$ and $1 \times 10^{5} \mathrm{rad} / \mathrm{h} \ldots \ldots \ldots .15$

5-1 Ferrocyanide Waste Tank Safety Schedule $\ldots \ldots \ldots \ldots \ldots \ldots$. . . . . . . .

\section{LIST OF TABLES}

3-1 Cyanide Mass Balance $\ldots \ldots \ldots \ldots \ldots \ldots \ldots \ldots \ldots \ldots \ldots \ldots \ldots \ldots \ldots \ldots \ldots .17$

3-2 Aging Rates as a Function of Temperature for Waste Simulant Experiments . . . 3-17 


\section{LIST OF TERMS}

$\begin{array}{ll}\text { cal/g } & \text { calories per gram } \\ \text { DNFSB } & \text { Defense Nuclear Facilities Safety Board } \\ \text { DOE } & \text { U.S. Department of Energy } \\ \text { DOE-RL } & \text { U.S. Department of Energy, Richland Operations Office } \\ \text { DQO } & \text { data quality objectives } \\ \text { EA } & \text { environmental assessment } \\ \text { EMI } & \text { electromagnetic induction } \\ \text { FAI } & \text { Fauske and Associates, Inc. } \\ \text { FSAR } & \text { Final Safety Analysis Report } \\ \text { FTIR } & \text { Fourier transform infrared spectroscopy } \\ \text { FY } & \text { fiscal year } \\ \text { g-mol } & \text { gram-mole } \\ \text { GAO } & \text { U.S. General Accounting Office } \\ \text { IR } & \text { infrared } \\ \text { ISB } & \text { interim safety basis } \\ \text { J/g } & \text { Joules per gram } \\ \text { kW } & \text { kilowatt } \\ \text { LANL } & \text { Los Alamos National Laboratory } \\ \text { LOW } & \text { liquid observation well } \\ \text { NASA } & \text { National Aeronautics and Space Administration } \\ \text { NIR } & \text { near infrared } \\ \text { PNNL } & \text { Pacific Northwest National Laboratory } \\ \text { ppmv } & \text { parts per million by volume } \\ \text { ppm } & \text { parts per million by weight } \\ \text { rad/h } & \text { Rads per hour } \\ \text { SA } & \text { safety assessment } \\ \text { SEM } & \text { scanning electron microscope/microscopy } \\ \text { SST } & \text { single-shell tank } \\ \text { TC } & \text { thermocouple } \\ \text { TCR } & \text { tank characterization report } \\ \text { TMACS } & \text { Tank Monitor and Control System } \\ \text { TOC } & \text { total organic carbon } \\ \text { USQ } & \text { unreviewed safety question } \\ \text { WHC } & \text { Westinghouse Hanford Company } \\ \text { wt\% } & \end{array}$


This page intentionally left blank. 


\subsection{INTRODUCTION}

\subsection{PURPOSE}

This quarterly report provides a status of activities underway on the Ferrocyanide Safety Issue at the Hanford Site, including actions in response to Defense Nuclear Facilities Safety Board (DNFSB) Recommendation 90-7 (FR 1990). In March 1991, a DNFSB implementation plan (Cash 1991) responding to the six parts of Recommendation 90-7 was prepared and sent to the DNFSB. A ferrocyanide safety program plan addressing the total Ferrocyanide Safety Program, including the six parts of DNFSB Recommendation 90-7, was released in October 1994 (DOE 1994b). Activities in the program plan are underway or are completed, and the status of each is described in Sections 2.0 and 3.0 of this report.

\subsection{QUARTERLY HIGHLIGHTS}

- Final approval was received (Kinzer 1996) from the U.S. Department of Energy (DOE), Richland Operations Office (DOE-RL) on June 25, 1996 to remove the four C-Farm Ferrocyanide tanks (241-C-108, C-109, C-111, and C-112) from the Wyden Amendment Watch List (Public Law 101-510, 1990).

- The technical basis safety document for removal of the remaining 14 ferrocyanide tanks from the Wyden Amendment Watch List, and for final resolution of the Ferrocyanide Safety Issue (WHC-SD-WM-SARR-038, Revision 1), was completed and submitted to DOE-RL on July 3, 1996 (Bacon 1996c, Meacham et al. 1996). Approval to remove the remaining 14 tanks by DOE will resolve the Ferrocyanide Safety Issue and complete the Ferrocyanide Safety Program.

- The final aging report (PNNL-11211) was issued on June 28, 1996 and summarizes all work completed to date on aging studies (Lilga et al. 1996). The information was key to completing the technical basis safety document, WHC-SD-WM-SARR-038, Rev. 1.

- The final analytical report was completed for ferrocyanide tank 241-BY-104 this quarter (Benar 1996b). The final results were incorporated into the technical basis safety documentation.

- The final analytical report was completed for 241-BY-110 this quarter and the tank characterization report (TCR) is in preparation with a scheduled August 1996 issuance date (Schreiber 1966). No sample obtained had mean exothermic reactions (on a dry weight basis) exceeding the Ferrocyanide Data 
Quality Objectives (DQO) (Meacham et al. 1995) limit of 480 Joules per gram $(\mathrm{J} / \mathrm{g})$. In addition, the observed cyanide concentrations were well below the ferrocyanide DQO limit.

\subsection{REPORT FORMAT}

Progress reports for activities under each of the six parts of DNFSB Recommendation 90-7 are arranged in the same order as the program plan (DOE 1994b). The arrangement also follows the same order provided in Recommendation 90-7. To report on progress, each part of the recommendation is repeated in italics, followed by paragraphs explaining the scope of work on each part or subpart of the recommendation. Subheadings for each task activity report the following:

- Progress During Reporting Period

- Planned Work for Subsequent Months

- Problem Areas and Action Taken

- Milestone Status.

\subsection{BACKGROUND}

Since the mid-1940's, various high-level radioactive wastes from defense operations have accumulated at the Hanford Site in underground storage tanks. During the 1950's, additional tank storage space was required to support the defense mission. To obtain this additional storage volume within a short time period, and to minimize the need for constructing additional storage tanks, Hanford Site scientists developed a process to scavenge ${ }^{137} \mathrm{Cs}$ and ${ }^{90} \mathrm{Sr}$ from tank waste liquids. In implementing this process, approximately 140 metric tons (154 tons) of ferrocyanide were added to waste that was later routed to a number of Hanford Site single-shell tanks (SSTs) (Sloat 1954, 1955).

In the presence of oxidizing material such as sodium nitrate and/or nitrite, ferrocyanide can be made to react exothermically by heating it to high temperatures or by applying an electrical spark of sufficient energy (Cady 1993). However, fuel, oxidizers, and temperature are all important parameters. If fuel, oxidizers, or high temperatures (initiators) are not present in sufficient amounts, then a runaway or propagating reaction cannot occur.

In 1990, little was known about the potential hazards of a ferrocyanide-nitrate/nitrite reaction in Hanford Site SSTs. The existing safety analysis report (Smith 1986) and subsequent analyses such as the 1987 environmental impact statement (DOE 1987) did not adequately define the conditions necessary to preclude propagating reactions in the ferrocyanide waste. 
Because the safety envelope was not adequately defined by existing analyses, an inadequacy existed in the authorization basis*, and an unreviewed safety question (USQ) was declared (Deaton 1990).

Based on the knowledge gained from simulant studies, theoretical analyses, and analyses of actual waste samples, safety criteria were defined for the ferrocyanide waste (Postma et al. 1994a). These criteria were reviewed and accepted by outside reviewers and reviewers within DOE. The USQ was closed on March 1, 1994 by the DOE Assistant Secretary for Environmental Restoration and Waste Management (Sheridan 1994b).

In September 1990, an ad hoc task force report (Kress et al. 1990) recommended that studies be performed to provide information on (1) the potential for a ferrocyanide-nitrate/nitrite explosion; (2) the conditions necessary in the tanks to initiate an explosion; and (3) the potential consequences of such an occurrence. The U.S. General Accounting Office (GAO) advised the Secretary of Energy to implement these recommendations (Peach 1990). A closeout report addressing all three GAO recommendations was submitted to DOE in June 1994 (Payne 1994b). The closeout report summarizes the progress made on determining the potential for ferrocyanide reactions in Hanford Site ferrocyanide tanks, and the conditions necessary to sustain an exothermic ferrocyanide reaction.

In March 1989, based on process knowledge, process records, transfer records, and log books, 22 Hanford Site tanks were identified as potentially containing 1,000 gram-moles $(\mathrm{g}-\mathrm{mol})^{* *}(211 \mathrm{~kg}[465 \mathrm{lb}])$ or more of ferrocyanide as the $\mathrm{Fe}(\mathrm{CN})_{6}^{+}$anion (Nguyen 1989). Two additional ferrocyanide tanks were identified in January 1991 (Borsheim and Cash 1991), increasing the number of ferrocyanide tanks to 24 . To avert possible injury to personnel and damage to the facility or environment, strict controls were identified for these and other safety issue tanks in Operating Specifications for Watch List Tanks (WHC 1990). Tanks identified by this document (see WHC 1996 for the latest revision) have been commonly referred to as Watch List tanks. In October 1990 (Deaton 1990), the Ferrocyanide Safety Issue was declared a USQ (see Section 2.1) because the safety envelope for these tanks was no longer considered to be bounded by the existing safety analysis report (Smith 1986).

The DOE authorization basis characterizes the facility design basis and operational requirements for each nuclear facility. The authorization basis is described in documents such as facility safety analysis reports and other safety analyses, hazard classification documents, technical safety requirements, DOE-issued safety evaluation reports, and facility-specific commitments such as safety assessments for specific tank operations and the Interim Safety Basis (ISB) (Wagoner 1993).

*The $1,000 \mathrm{~g}$-mol criterion has since been replaced with a $115 \mathrm{calories}$ per gram (cal/g) $(480 \mathrm{~J} / \mathrm{g})$ fuel concentration criterion. See Section 4.1 for discussion. 
In November 1990, the Wyden Amendment was enacted (Public Law 101-510, 1990). This law required the identification of Hanford Site tanks that may have a serious potential for release of high-level waste (see Section 4.0). In February 1991, the 24 ferrocyanide tanks were among the tanks identified (Harmon 1991), and were included in the subsequent July 1991 report to Congress that responded to the Wyden Amendment (Watkins 1991). However, re-examination of the historical records indicated that 6 of the 24 tanks did not contain the requisite 1,000 g-mol of ferrocyanide (Borsheim and Simpson 1991). Therefore, these six tanks should not have been included on the Watch List nor identified in the response to the Wyden Amendment. The six tanks were subsequently removed from the Watch List (Anttonen 1993, Sheridan 1994b). 


\subsection{FERROCYANIDE SAFETY DOCUMENTATION}

The USQ process depends on an authorization basis that describes those aspects of the facility design basis and operational requirements relied on by DOE to authorize operation. The authorization basis is described in documents such as facility safety analysis reports and other safety analyses, hazard classification documents, technical safety requirements, DOE-issued safety evaluation reports, and facility-specific commitments such as safety assessments (SAs), the ISB, and the Final Safety Analysis Report (FSAR) that is scheduled for completion in November 1996. The potential hazards of a ferrocyanide-nitrate/nitrite reaction were discovered to represent an inadequacy in the authorization basis (Smith 1986). The Ferrocyanide USQ was closed on March 1, 1994 by the DOE Assistant Secretary for Environmental Restoration and Waste Management (Sheridan 1994a). Progress on the remaining safety documentation for resolving the Ferrocyanide Safety Issue is reviewed in this section.

Safety and Environmental Assessments. SAs are documents prepared to provide the technical basis for assessing the safety of a proposed activity and to provide proper controls to maintain safety. The SA and the accompanying environmental assessment (EA) for that operation provide the basis for DOE authorization of the proposed activities. SAs have been approved for headspace sampling of all ferrocyanide tanks, waste surface sampling, push-mode and rotary-mode core sampling, thermocouple (TC)/instrument tree installation in sound and assumed-leaker tanks, and removal of pumpable liquid (interim stabilization). A generic EA covering all proposed operations in the tank farms was approved and a Finding of No Significant Impact was issued by DOE (Gerton 1994). Approval of the generic EA provides adequate National Environmental Policy Act coverage for the planned Ferrocyanide Safety Program activities.

The authorization basis for intrusive tank operations was combined into one document, the ISB, which was approved in November 1993 (Wagoner 1993). Safety documentation concerning the ferrocyanide hazard was updated to reflect the approved ferrocyanide safety criteria and closure of the Ferrocyanide USQ. This information is also being incorporated into the draft FSAR that will replace the ISB when approved by DOE.

Hazard Assessment. A report assessing the ferrocyanide waste tank hazards was issued in July 1992 (Grigsby et al. 1992). The report reviewed the understanding of the ferrocyanide hazard at that time, and presented an integrated evaluation and interpretation of historical data and then-available information. Additional data are now available on the potential for exothermic ferrocyanide reactions in Hanford Site SSTs.

The ferrocyanide hazard assessment document, Assessment of the Potential for Ferrocyanide Propagating Reaction Accidents, WHC-SD-WM-SARR-038, Revision 0 (Grigsby et al. 1996a), was transmitted to DOE-RL on January 31, 1996. Minor comments were incorporated into the document as Revision $\mathrm{OA}$ and the document was retransmitted to DOE-RL on March 19, 1996 (Grigsby et al. 1996b). Revision 0A was subsequently 
forwarded to the DNFSB by DOE-RL on April 10, 1996 (Trine 1996). The document provided the technical basis for removal of the four C-Farm ferrocyanide tanks (241-C-108, C-109, C-111, and C-112) from the Watch List. Approval for their removal from the Watch List was received from DOE-RL on June 25, 1996 (Kinzer 1996).

Revision 1 of the document (Meacham et al. 1996) was completed this quarter, addressing all 18 ferrocyanide tanks, and the document was transmitted to DOE-RL on July 3, 1996. The transmittal letter (Bacon 1996c) requested approval to remove the remaining 14 ferrocyanide tanks from the Watch List and for final resolution of the Ferrocyanide Safety Issue based on Revision 1 of the document. The Chemical Reaction Subpanel of the Tanks Advisory Panel reviewed the document in June 1996, and their comments were addressed and incorporated. Technical information from all Ferrocyanide Safety Program tasks was compiled into this document, and following DOE approval, the ISB and draft FSAR will be revised accordingly.

Ferrocyanide Program Plan. A ferrocyanide program plan was submitted to the DNFSB in December 1994 (O'Leary 1994). The program plan outlines activities planned to address DNFSB Recommendation 90-7, to meet the Wyden Amendment requirements (Public Law 101-510, 1990), and to remove the remaining ferrocyanide tanks from the Watch List. All ferrocyanide program activities are scheduled to be completed by the end of fiscal year (FY) 1997. However, an increased understanding of radiolytic and chemical degradation (aging) of ferrocyanide indicates that little ferrocyanide remains, and core sampling of all the tanks is not required. Core sampling and analyses of only those tanks that bound aging (i.e., tanks with conditions least conducive to aging) could result in resolution of the Ferrocyanide Safety Issue much earlier and at a substantially reduced cost. Ferrocyanide tanks that have not been sampled to date will eventually be sampled as part of other safety issues or DQOs, such as the Organic Safety Program or the Safety Screening, Historical, or Retrieval DQOs (Dukelow et al. 1995, Simpson and McCain 1996).

\section{- Milestone Status}

- January 31, 1996. Westinghouse Hanford Company issues documentation supporting safety issue resolution for the four C-Farm tanks and recommends their removal from the Wyden Amendment Watch List (Public Law 101-510, 1990). The Assessment of the Potential for Ferrocyanide Propagating Reaction Accidents, WHC-SD-WM-SARR-038, Revision 0, was transmitted to DOE-RL as scheduled (Bacon 1996a, Grigsby et al. 1996a). All four C-Farm tanks were sampled earlier and data interpretation reports have been completed for these tanks.

The report was revised to incorporate informal comments received from DOE-RL and reissued with the same title, as WHC-SD-WM-SARR-038, Revision OA (Grigsby et al. 1996b). The revised report was transmitted to DOE-RL with a letter requesting that the four C-Farm tanks be removed 
from the Watch List on March 19, 1996 (Bacon 1996b). The report was subsequently forwarded to the DNFSB Staff on April 10, 1996 (Trine 1996).

- July 31, 1996. Westinghouse Hanford Company receives DOE approval to remove the four C-Farm ferrocyanide tanks from the Watch List. Approval was received from DOE on June 25, 1996, ahead of schedule (Kinzer 1996).

- July 31, 1996. Westinghouse Hanford Company prepares and submits the final ferrocyanide hazard assessment for DOE approval, providing the technical basis for removing all 18 ferrocyanide tanks from the Watch List, and resolution of the Ferrocyanide Safety Issue. The official due date for this milestone is August 30, 1996, with an enhanced date of July 3, 1996. The final ferrocyanide hazard assessment, (WHC-SD-WM-SARR-038, Revision 1 Meacham et al. 1996), was prepared and submitted for DOE approval on July 3, 1996 (Bacon 1996c).

- September 30, 1997. Westinghouse Hanford Company receives DOE approval for the Ferrocyanide Safety Issue resolution. It is anticipated that DOE will approve this request by September 30,1996, based on early submittal of the final hazard assessment document. 
This page intentionally left blank. 


\subsection{ACTIONS TO COMPLETE DNFSB RECOMMENDATION 90-7}

This section follows the format of the program plan (DOE 1994b) and describes all work associated with the Ferrocyanide Safety Program. Where applicable, each task activity is described relative to the DNFSB Recommendation (90-7.1 through 90-7.6). The specific part of the recommendation is given, followed by a summary of activities underway to respond to that part of Recommendation 90-7 (if not already closed out).

\subsection{ENHANCED TEMPERATURE MEASUREMENT}

"Immediate steps should be taken to add instrumentation as necessary to the SSTs containing ferrocyanide that will establish whether hot spots exist or may develop in the future in the stored waste. The instrumentation should include, as a minimum, additional thermocouple trees. Trees should be introduced at several radial locations in all tanks containing substantial amounts of ferrocyanide, to measure the temperature as a function of elevation at these radii. The use of infrared techniques to survey the surface of waste in tanks should continue to be investigated as a priority matter, and on the assumption that this method will be found valuable, monitors based on it should be installed now in the ferrocyanide bearing tanks."

\subsubsection{Instrument Trees}

All new instrument trees planned for the ferrocyanide tanks have been installed and this action was completed in August 1995. Originally, several new temperature measurement instruments were to be installed into each tank. This plan was modified to ensure that at least one instrument tree with replaceable temperature-sensing elements was in each ferrocyanide tank. The new trees have at least two operational temperature-sensing elements in the waste to ensure a true temperature measurement, and one or more elements in the headspace. The number of temperature sensing elements in the new trees is typically six, but some tanks with larger inventories of waste contain up to eight elements.

The decision to put only one new tree into each tank was based on the following: (1) many of the TC elements in the existing trees were returned to service in FY 1992, and measured temperatures are as expected (Bussell 1992); (2) thermal modeling (McLaren 1994a, 1994b) and an enhanced understanding of waste properties show that formation of hot spots in ferrocyanide tanks is not credible (Dickinson et al. 1993, Epstein et al. 1994); and (3) new calculations of tank heat content based on tank temperatures show lower values than previous estimates (Crowe et al. 1993, McLaren 1994a, 1994b).

There are two instrument trees in all but three ferrocyanide tanks (241-BY-106, BY-111, and BY-112). The instrument tree in tank 241-BY-106 already had replaceable temperature sensing elements, and tanks 241-BY-111 and BY-112 previously had no operable instrument 
trees. The instrument trees in the ferrocyanide tanks are monitored continuously by the Tank Monitor and Control System (TMACS). The older instrument trees are expected eventually to fail in a manner such that they cannot be repaired, and they will not be replaced. The highest temperatures recorded in each of the tanks for the quarter ending March 31, 1996 are listed in Appendix A, Table A-1.

- Status. The last of 16 new instrument trees were installed in the 18 ferrocyanide tanks in August 1995. A total of 33 working instrument trees and a TC element in each liquid observation well (LOW) of tanks 241-BY-111 and BY-112 are continuously monitored by TMACS. All work is complete for this task and DNFSB Recommendation $90-7.1$ is closed.

\subsubsection{Upgrades to Existing Temperature Monitoring Instrumentation}

This task determined the operability and accuracy of previously installed TC elements in the original 24 ferrocyanide Watch List tanks. The original and newly-installed instrument trees provide temperature measurements for each of the ferrocyanide tanks.

Field measurements were taken in 1991 on each TC element in the then-existing trees to determine the resistance and voltage across the junction, and across each lead to ground. The exact condition of each TC element was determined by resistance and voltage measurements (Bussell 1992). This work was completed in FY 1991 with a total of 265 TC elements evaluated. Work in FY 1992 focused on repair and recovery of 92 TC elements that were found to be failed or marginal in performance. This task was completed in FY 1992 for the Ferrocyanide Safety Program.

- Status. This task is complete for the Ferrocyanide Safety Program.

\subsubsection{Hot Spot Thermal Modeling}

Radioactive materials decaying in Hanford Site waste tanks generate heat. An early concern, raised when the ferrocyanide tanks first became a safety issue, was whether an exothermic excursion and local propagation could occur within the ferrocyanide waste if a sufficient concentration of ferrocyanide and a high enough temperature were present. This task examined the available temperature data from the ferrocyanide tanks in order to determine the heat load and temperatures as a function of depth and radial location. Sensitivity and parametric analyses were included to determine the magnitude of a hot spot that would have to exist for the waste to reach propagation temperatures.

Heat load analyses and thermal characteristics were completed for all ferrocyanide tanks in FY 1994 (McLaren 1994a, 1994b). The maximum heat load of any ferrocyanide tank, assuming worst-case conditions for soil moisture and thermal conductivity, was below 4.2 kilowatts (kW). Nominal heat loads calculated in 1994 (McLaren 1994a, 1994b) 
compared very favorably with those calculated independently in 1993 (Crowe et al. 1993). A dryout analysis was also completed and released in FY 1994 (Epstein et al. 1994). The report concluded that ferrocyanide sludge could not dry sufficiently to be chemically reactive during interim storage, either globally or locally. Dryout mechanisms evaluated included global evaporation, removal of liquid by leakage or pumping, boiling as a result of hot spots, and enhanced surface evaporation from hot spots. All activities were completed for this task in FY 1994.

- Status. This task is complete.

\subsubsection{Infrared Scanning System}

Infrared (IR) scanning systems are commercially available from numerous vendors. These systems are sensitive to changes of $\pm 0.3^{\circ} \mathrm{C}$ or less under ideal conditions, and offer promise for mapping surface temperature profiles in the ferrocyanide tanks. Thermal modeling performed on ferrocyanide tank 241-BY-104 suggested that if hot spots with temperatures of concern are possible, surface temperature differences might be great enough to be detected by IR mapping (McLaren 1993).

A position paper on the credibility of hot spots and the need for further IR scanning was issued in April 1993 (Dickinson et al. 1993). Further analyses have been performed to assess potential dryout of the ferrocyanide waste (Epstein et al. 1994). These reports examined potential mechanisms for forming hot spots. Analyses indicate that hot spots are not credible in ferrocyanide tanks. Based on these analyses, Westinghouse Hanford Company recommended that no further planning be pursued for IR scans for the purpose of detecting hot spots. Work on this Ferrocyanide Safety Program task was concluded at the end of FY 1993.

- Status. This task is complete.

\subsubsection{Cooling System Requirements}

The program plan for resolution of the Ferrocyanide Safety Issue (DOE 1994b) provided actions that would be taken to cool the ferrocyanide tanks if it were found that such cooling was necessary. Several tentative milestones, identified below, were established for use if a cooling system(s) were required. The concern at the time was that increasing temperatures could lead to loss of moisture within the ferrocyanide waste matrix. Immediate emergency actions that would be taken if increased temperatures were to occur are described in the Action Plan for Response to Abnormal Conditions in Hanford Site Radioactive Waste Tanks Containing Ferrocyanide (WHC-EP-0407, Revision 2 [Fowler 1994]). Types of cooling systems might include, but are not limited to, the following: (1) forced ventilation of the tank, using an existing or new exhauster system; (2) air conditioning the air to the tank; (3) adding humid air or mist; and (4) adding water to the tank. 
Based on the historical database, analytical data on samples from ferrocyanide tanks, and results from the Pacific Northwest National Laboratory (PNNL) aging test activity, none of the 18 ferrocyanide tanks contain a high enough concentration of ferrocyanide for a propagating reaction to occur. Because dryout of the waste under the present storage conditions is not credible, a special cooling system for the ferrocyanide tanks is not considered necessary (Epstein et al. 1994).

- Status. This task is complete.

\subsection{CONTINUOUS TEMPERATURE MONITORING}

"The temperature sensors referred to above [Recommendation 90-7.1] should have continuous recorded readouts and alarms that would signal at a permanently manned location any abnormally high temperatures and any failed temperature instrumentation."

This task provided continuous monitoring of presently installed (and operable) temperature-sensing elements for the ferrocyanide tanks. New instrument trees were connected to TMACS shortly after they were installed into each tank, resulting in continuous temperature monitoring in the ferrocyanide tanks. All data are collected automatically at the continuously manned Computer Automated Surveillance System Operator Control Station. The monitoring system is independent of the Computer Automated Surveillance System and displays data to an operator on request. Trend data on selected points are available for display in numeric or graphic form.

The TMACS system, which became operational in September 1991, provides alarms for a change in the value of any temperature point. Alarms, if they occur, trigger an audible annunciator and are logged immediately to hard copy. An alarm summary display provides a list of the most recent alarms in order of occurrence. Each alarm can be identified by point and time of occurrence. Operator acknowledgement of the alarm will silence the audible annunciator. Signal conditioning and multiplexing are performed locally at each tank, eliminating the need to transmit low-level signals to the tank farm boundary and reducing cable runs. Electronic noise, extension wire corrosion, and thermal gradients are also reduced.

- Status. Temperatures measured by 33 instrument trees and two TC elements in LOWs in the ferrocyanide tanks are being monitored continuously by TMACS. This work was completed in August 1995, and DNFSB Recommendation 90-7.2 is closed. The highest temperatures recorded in each of the tanks for the quarter ending June 30, 1996 are listed in Appendix A, Table A-1. This task is complete. 


\subsection{COVER GAS MONITORING}

"Instrumentation should also be installed to monitor the composition of cover gas in the tanks, to establish if flammable gas is present."

\subsubsection{Interim Flammable Gas Monitoring}

Flammable and toxic gas monitoring and analyses in the ferrocyanide tanks and other Hanford Site waste tanks are continuing. This effort was transferred to the Tank Vapor Monitoring Program, which is coordinating interim gas monitoring of the ferrocyanide tanks and tanks involved with the tank vapor program. Tank headspaces are measured for flammability using a commercial combustible gas monitor (calibrated with pentane gas), and are monitored for potential toxic gases using an organic vapor monitor and Dräger* tubes. Headspace characterization of all the Hanford Site high-level waste tanks is continuing using sorbent tubes placed on the end of tubes lowered into the headspace, and SUMMA** canisters that collect gas samples topside. The initial headspace sampling was done in several tank locations (i.e., from two widely separated risers) and at three elevations in the headspace. Reviews of sampling data and modeling (Wood 1992, Claybrook and Wood 1994, Postma et al. 1994b) indicate that the headspace is well mixed and that sampling from one riser at one elevation is adequate.

- Status. Headspace sampling of all 18 ferrocyanide tanks as required for this task was completed in May 1995. The results are summarized in Appendix A, Table A-2. Headspace sampling of the ferrocyanide tanks and other Hanford Site high-level waste tanks will continue on a periodic basis as part of the Tank Vapor Monitoring Program. DNFSB Recommendation 90-7.3 is closed.

\subsubsection{Continuous Gas Monitoring}

The possibility that localized concentrations or stratification of gases exist in the tanks was evaluated. A modeling study was conducted to determine airflow patterns in the headspace of tank 241-C-109, and to evaluate the amount of mixing and the local gas concentrations that could occur. Since the study revealed that the gases in the tank are well mixed and follow Graham's law for gaseous diffusion, an analysis of a second tank was considered unnecessary (Wood 1992). Studies completed since that time also confirm that conclusion (Claybrook and Wood 1994, Postma et al. 1994b).

*Trademark of Drägerwerk Aktiengesellschaft, Inc., Lubeck, Germany; also National Draeger, Inc., Pittsburgh, Pennsylvania.

**Trademark of Molectrics, Inc., Cleveland, Ohio. 
The need for continuous gas monitoring was addressed in a report that also assessed the potential for cyclic venting and the possibility of accumulating flammable gases (Fowler and Graves 1994). The report concluded that continuous flammable gas monitoring in ferrocyanide tanks was not warranted based on (1) the low concentration of flammable gases found to date; (2) anticipated low ferrocyanide concentrations because of waste aging; (3) analytical results from tanks $241-\mathrm{C}-109$ and $\mathrm{C}-112$ showing that the fuel concentration in the tanks is much lower than postulated by flowsheet values and operating records; and (4) calculations of hydrogen accumulation using realistic generation values and passive ventilation assumptions. Vapor sampling of all 18 ferrocyanide tanks has corroborated that flammable gas concentrations in the ferrocyanide tanks are too low to be of concern. No further activities are planned for this task.

- Progress During Reporting Period. This task is complete. DOE has concurred that no continuous gas monitoring is required (O'Leary 1994).

\subsection{FERROCYANIDE WASTE CHARACTERIZATION}

"The program of sampling the contents of these tanks should be greatly accelerated. The proposed schedule whereby analysis of two core samples from each single-shell tank is to be completed by September 1998 is seriously inadequate in light of the uncertainties as to safety of these tanks. Furthermore, additional samples are required at several radii and at a range of elevations for the tanks containing substantial amounts of ferrocyanide. "

Characterization of the waste in the ferrocyanide tanks is necessary to (1) guide further chemical reaction studies with the ferrocyanide waste simulants, if necessary; (2) determine actual chemical and physical properties of the waste; (3) determine how the ferrocyanide waste can be safely stored until retrieval and disposal actions are completed; and (4) apply the study results to the final remediation (exhumation and vitrification) of the waste. This information will be used to resolve the Ferrocyanide Safety Issue.

The important reactive materials that may be present in the ferrocyanide tanks are fuel (ferrocyanides, sulfides, and reduced carbon species such as organic complexants), oxidants (nitrates and nitrites), and inerts or diluents (including phosphates, aluminates, sulfates, carbonates, oxides, hydroxides, and most importantly water). The location of fission products such as ${ }^{137} \mathrm{Cs}$ and ${ }^{90} \mathrm{Sr}$ is important because these products are heat sources and potential source terms in postulated radiological releases from a hypothetical ferrocyanide reaction. The water content of the waste is very important because the high heat capacity and heat of vaporization of water make it an effective inerting material. Water can prevent a sustained combustion or a propagating reaction if sufficient fuel is present; wet ferrocyanide material would require drying before it could react or propagate. 


\subsubsection{Ferrocyanide Tank Waste Sampling and Analyses}

Tank Sampling. Rotary-mode and push-mode sampling capabilities, auger surface sampling, and grab sampling (primarily for liquids) are used to obtain waste samples from the Watch List tanks. Tanks without saltcake and with relatively soft waste solids can be sampled by the push-mode method. If a hard saltcake or sludge layer is present, rotary-mode sampling is used. Auger sampling may also be used if the depth of waste is nominally less than $60 \mathrm{~cm}$. Grab sampling is used for tanks containing supernatant and soft sludge waste and has not been employed in the ferrocyanide tanks.

Each core consists of several $48-\mathrm{cm}$ segments (or portions thereof) depending on the depth of the waste in the tank. The sludge layer in these cores is normally divided into four $12-\mathrm{cm}$ subsegments if a full 48-cm segment is obtained; otherwise the sample is subdivided into one or more subsegments that are at least $12 \mathrm{~cm}$ in length. If the tank contains a saltcake layer, the saltcake segments are divided into only two subsegments. Segments that contain both sludge and saltcake are divided such that the two types of waste are separated into separate samples. Process flowsheet knowledge, tank historical data, and results obtained from tests with ferrocyanide sludge simulants are used to supplement the analytical results from core sampling.

The priority for sampling ferrocyanide tanks was changed to reflect the need to determine the reactive properties of the contents. In response to DNFSB Recommendation 93-5 to expedite sampling and analyses required to address safety issues in the Hanford Site Watch List tanks (DOE 1994a), the analysis plans for future ferrocyanide tank core samples (and the plans for other Watch List tanks) were revised. The Watch List tanks were given priority for core sampling, and the number of required analytes was reduced. Analyte selection was refocused primarily on safety-related properties.

- Progress During Reporting Period. Analytical analyses were completed for ferrocyanide tank 241-BY-104, and the final laboratory report was issued on June 25, 1996 (Benar 1996b). Results were tabulated in the previous quarterly report (Cash and Meacham 1996). Samples obtained met the requirements specified in the Ferrocyanide DQO document (Meacham et al. 1995). The 45-day analytical report (Benar 1996a) was issued the previous quarter. The TCR for this tank is scheduled for release next quarter.

Samples from the attempts to perform push-mode core sampling of tanks 241-BY-105 (riser 12A/core 108) and BY-106 (riser 5/core 121) continued to be analyzed even though the sampling event did not meet the Ferrocyanide DQO requirements. These two tanks were sampled during the first quarter of FY 1996 but no sludge segments were recovered because the downforce limit was reached and sampling was stopped. The final analytical reports for tanks 241-BY-105 and BY-106 will be issued next quarter. Since neither of these cores extended to the sludge portion of the tank waste, no tabular results will be presented in this report. Some exotherms were detected, two of which exceeded the $480 \mathrm{~J} / \mathrm{g}$ 
exceeded the $480 \mathrm{~J} / \mathrm{g}$ notification limit. However, corresponding total organic carbon (TOC) values were also significant (ranging from 0.07-0.19\%) and total cyanide values were very low (5-10 parts per million [ppm]).

The final analytical report was completed for 241-BY-110 on May 24, 1996 (Schreiber 1996), and the TCR is now being prepared with a scheduled issuance of August 1996. None of the samples obtained had mean exothermic reactions (on a dry weight basis) exceeding the Ferrocyanide DQO limit of $480 \mathrm{~J} / \mathrm{g}$. The samples that demonstrated some energetics were at least 25 percent water, which eliminates the potential for a propagating reaction. In addition, the observed cyanide concentrations were well below the ferrocyanide DQO limit. Nickel concentrations compared favorably with historical estimates and indicate that ferrocyanide has substantially decomposed.

- Planned Work For Subsequent Months. There are no present plans to apply the Ferrocyanide DQO (Meacham et al. 1995) to the unsampled ferrocyanide tanks presently on the Watch List; however some of these tanks will be sampled for other issues as mentioned in Section 2.0. The ferrocyanide hazard assessment document has presented the case that further sampling of ferrocyanide tanks is not necessary.

The final analytical reports and TCRs for tanks 241-BY-104, BY-105, BY-106 and BY-110 are scheduled to be issued next quarter.

- Problem Areas and Actions Taken. There are none, assuming the hazard assessment document, WHC-SD-WM-SARR-038, Revision 1 (Meacham et al. 1996), is approved by DOE.

- Milestone Status.

- December 31, 1995. Westinghouse Hanford Company obtains core samples from five additional ferrocyanide tanks. Only one ferrocyanide tank, 241-BY-104, was successfully sampled in November 1995. Attempts to obtain push-mode core samples from tanks 241-BY-105 and BY-106 were discontinued when the downforce limit was reached for the drill string. There are currently no plans to sample additional ferrocyanide tanks for resolving the Ferrocyanide Safety Issue. This milestone has been superseded by the final hazard assessment document (WHC-SD-WM-SARR-038, Revision 1), which was issued July 3, 1996 (Meacham et al. 1996). 
- March 31, 1996. Westinghouse Hanford Company completes data interpretation reports, available for public release, for five ferrocyanide tanks. This milestone date was not met because of the delays encountered in rotary-mode sampling of the tanks. Assuming the final hazard assessment document is accepted, completion of this milestone is not necessary to resolve the Ferrocyanide Safety Issue. TCRs will be issued next quarter for the four ferrocyanide tanks (241-BY-104, BY-105, BY-106, and BY-110) most recently sampled.

- July 31, 1996. Westinghouse Hanford Company obtains core samples from the remaining ferrocyanide tanks. This milestone is not required for resolution of the Ferrocyanide Safety Issue, assuming the hazard assessment document is accepted.

- October 31, 1996. Westinghouse Hanford Company completes data interpretation reports, available for public release, for the remaining ferrocyanide tanks. This milestone is not required for resolution of the safety issue, assuming the hazard assessment document is accepted.

Infrared Spectroscopy Analyses. The collection of near-infrared (NIR) spectra from archived waste tank core samples, with various chemical matrices using a Fourier transform infrared spectrometry (FTIR)-based fiber optics method, was completed in FY 1995.

Final reports summarizing IR work were issued at the end of FY 1995 (Rebagay et al. 1995, Reich et al. 1995, Douglas and Reich 1995).

- Status. This task was completed in FY 1995. No further work is planned in this area in support of the Ferrocyanide Safety Program.

Mössbauer Spectroscopy. A small task on Mössbauer spectroscopy, previously supported by the Ferrocyanide Safety Program, is investigating the physical and chemical nature of iron within tank waste. The National Aeronautics and Space Administration (NASA) has developed a miniaturized Mössbauer spectrometer that is small enough to perform elevation scans within the LOWs of the Hanford Site waste tanks. Iron is a major constituent of ferrocyanide waste, and information about its location and composition in the tanks supports safe interim storage and eventual retrieval of the waste. The Mössbauer program represents a cooperative venture between Westinghouse Hanford Company, DOE, and NASA. The contact at NASA is Dr. Richard Morris at the Johnson Space Center in Houston, Texas.

A decision was made in January 1996 to delete the scope of work in this task from the Ferrocyanide Safety Program, and a financial change request was approved at that time. 
The task is continuing at the Hanford Site under a funding source different from the Ferrocyanide Safety Program. Progress will no longer be reported in the quarterly reports.

- Status. Funding from the Ferrocyanide Safety Program for this task was terminated in January 1996 when a financial change request was approved by Westinghouse Hanford Company and DOE-RL. The task was deleted from the scope of the Ferrocyanide Safety Program because completion of the effort is not required to resolve the Ferrocyanide Safety Issue (planned by the end of FY 1996). The Mössbauer spectrometer task is continuing under a separate funding source and no further progress will be reported in the ferrocyanide quarterly reports.

Scanning Electron Microscopy. Scanning electron microscopy (SEM) is a small task that is investigating the chemical and physical properties of waste stored in the Hanford Site high-level waste tanks. Studies to further refine what is known about the chemical and physical properties of ferrocyanide tank waste could continue if they were necessary for resolving the Ferrocyanide Safety Issue. However, it has been shown with confidence that the ferrocyanide concentration in the tanks has significantly degraded (aged) to the point where the fuel value is much too low to support a propagating reaction. The task now is to prepare a final technical basis safety document that will resolve the Ferrocyanide Safety Issue by September 1996, so that the 18 tanks can be removed from the Watch List.

A decision was made in January 1996 to delete the scope of work in this task from the Ferrocyanide Safety Program and a financial change request was approved at that time. The task is continuing at the Hanford Site under a funding source different from the Ferrocyanide Safety Program. Progress will no longer be reported in the quarterly reports.

- Status. Funding from the Ferrocyanide Safety Program for this task was terminated in January 1996 when a financial change request was approved by WHC and DOE-RL. The task was deleted from the scope of the Ferrocyanide Safety Program because completion of the effort is not required to resolve the Ferrocyanide Safety Issue (planned by the end of FY 1996). The SEM task is continuing under a separate funding source and further progress will not be reported in the ferrocyanide quarterly reports.

\subsubsection{Estimation of Water Content}

Methods for determining water concentrations in Hanford Site waste tanks are being developed using sample data analyses and state-of-the-art surveillance systems. This work was originally sponsored by the Ferrocyanide Safety Program, but it was transferred to the Organic Safety Program at the beginning of FY 1996. Two in situ moisture monitoring technologies are currently under development: neutron diffusion and electromagnetic induction (EMI). Initial development of NIR spectroscopy for determining the water content of Hanford Site tank waste was completed in FY 1994 at the University of Washington 
Center for Process Analytical Chemistry (Reich et al. 1994), and by Westinghouse Hanford Company in FY 1995 (Rebagay et al. 1995, Reich et al. 1995). A report examining moisture-monitoring technologies was completed in April 1993 (Meacham et al. 1993).

The water content of reactive waste can be an extremely important factor in ensuring the safety of the Hanford Site tank waste. The water concentration within the waste will determine whether or not it will react and propagate. If sufficient water is present, a chemical reaction cannot start. Recent work by Fauske and Associates, Inc. (FAI) has shown that as little as $5 \mathrm{wt} \%$ unbound water in a stoichiometric reactive mixture will prevent the mixture from igniting and burning when a significant ignition source is applied (Fauske 1996). Water may become the prime safety factor for the organic waste tanks to ensure that the waste is stored safely. For the ferrocyanide tanks it has been shown that the ferrocyanide content is insufficient for the waste to propagate, so the presence of water becomes a second safety barrier ensuring that the tanks are safe.

Neutron Diffusion. Well-logging techniques, coupled with computer modeling, were developed and applied to an existing neutron probe to determine information about the water concentrations, material interfaces, and other waste characteristics in the ferrocyanide tanks. Using the knowledge gained from computer modeling, in situ measurements, and experimental calibration data with the current in-tank liquid level neutron probe (Watson 1993), prototype moisture measurement neutron probes were developed. This system consists of three neutron probes: a near-field thermal neutron probe, a far-field thermal neutron probe, and a far-field epithermal neutron probe. This improved system would primarily be used to determine the axial moisture concentration profile within the ferrocyanide tanks.

Moisture measurement using neutron diffusion is an established technology. The technique uses a neutron source and one or more neutron detectors. The thermal neutrons reaching a detector originate as fast neutrons from the source and are slowed or absorbed by the medium. Because hydrogen atoms are effective at slowing down neutrons, the detector response is a strong function of the surrounding moisture concentration.

Two methods are generally used in the measurement of moisture concentration around wells using neutron diffusion. The first method, the moisture gauge, has a short source-to-detector spacing on the order of 0 to $10 \mathrm{~cm}$ (near-field). The response of a moisture gauge is characterized by an increase in detector response with increasing moisture concentration of the surrounding medium. The second method, the neutron $\log$, often has two detectors with longer source-to-detector spacings on the order of 20 to $50 \mathrm{~cm}$ (far-field). The detectors in a neutron log arrangement exhibit a decreased response to increased moisture concentrations. The detector placed at the shorter spacing is used to correct the response of the longer-spaced detector for borehole effects. 
Tank moisture measurements are taken from within LOWs. The LOWs are permanently installed sealed pipes that extend from the riser top through the tank waste to near the tank bottom. The LOWs allow axial information about the surrounding waste materials to be obtained using certain detectors.

The initial design and prototype tests were completed for a new surface moisture measurement neutron probe in FY 1995, and results and progress on this task were reported in Watson (1993), Finfrock et al. (1994), and (Lipke 1995). This effort was transferred to the Organic Safety Program, and no additional development work will be conducted for the Ferrocyanide Safety Program.

- Status. This task was transferred to the Organic Safety Program at the end of FY 1995, and progress on this ongoing task will no longer be reported in the ferrocyanide quarterly reports.

Electromagnetic Induction Probe. The purpose of this task is to deploy the EMI probe in the LOWs or on top of the waste surface, to measure moisture concentration. EMI probes operate by creating a magnetic field that induces current in a conductive medium. This induced current can be measured and is related to the media conductivity. The higher the electrical conductivity, the higher the free moisture content in the tank waste.

The EMI probe is designed with four separate coils of wire that can be either exciting coils or sensing coils. The present configuration uses one coil as the exciting coil and three coils as the sensing coils. This configuration allows three different depths of penetration during one scan. The electronics can be programmed to use four frequencies during one scan, so the information acquired will be four frequencies at three different coil spacings. This information will be useful in separating the environment near the LOW from the environment far from the LOW. Two different EMI probes have been built, with different coil spacing and turns per coil, to determine in-tank responses.

EMI probes were deployed in tanks 241-BY-104, BY-106, BY-107, BY-111, BY-112, TY-103, TX-118, TX-114 (3 LOWs), S-105, and S-106. Observations of the in-tank acquired data allowed some conclusions about EMI to be made: (1) the system is sensitive to loss of hydraulic conductivity, which occurs at approximately 0.08 to 0.12 volume fraction of liquid (depending on porosity); (2) the scan can interrogate multiple depths simultaneously; (3) EMI is sensitive to small changes in material properties; (4) the EMI method measures conductivity directly, while moisture interpretation requires some assumptions; (5) EMI results are affected by temperature, so compensation is required; and (6) the EMI method is strongly affected by ferromagnetic items. Reports have been issued on this work (Crowe and Wittekind 1995, Wittekind and Crowe 1996). The remaining development effort was transferred to the Organic Safety Program at the end of FY 1995.

- Status. This task was transferred to the Organic Safety Program at the end of FY 1995, and progress on this ongoing task will no longer be reported in the ferrocyanide quarterly reports. 


\subsubsection{Moisture Retention Properties of Ferrocyanide Sludge and Saltcake Simulants}

The water content of ferrocyanide sludge, if sufficient, will prevent exothermic ferrocyanide/nitrate-nitrite reactions. Studies were completed to evaluate the water retention properties of ferrocyanide tank sludge and saltcake simulants as they relate to possible waste tank leaks, tank stabilization by pumping, and possible evaporation from exposed surfaces. Previous work has shown that ferrocyanide sludge cannot dry sufficiently to be chemically reactive during interim storage, either globally or locally (Epstein et al. 1994). Dryout mechanisms evaluated included global evaporation, removal of liquid by leakage or pumping, boiling as a result of hot spots, and enhanced surface evaporation from hot spots. Recent work focused on water retention in saltcake material, especially after a tank has been interim-stabilized. This work was supported by the Ferrocyanide Safety Program until the end of FY 1995, but was transferred to the Organic Safety Program at the beginning of FY 1996.

Modeling calculations were performed to estimate the water-retaining capability of ferrocyanide waste in typical Hanford Site tank systems. The effort focused on evaluating the impact of consolidation and surface evaporation processes. Computer models were used to estimate retention of water within the matrix and to determine surface drying of sludge and saltcake waste. To accomplish these objectives, the hydraulic properties of actual sludges and saltcake porous media were compared with tested waste simulants, and their physical properties were correlated.

Modeling was also performed to examine the resistance of saltcake waste to gravity drainage and surface evaporation. Under the influence of gravity, saturated saltcake will drain when liquid is pumped out and when a tank is stabilized. In contrast, sludge does not readily drain and the interstitial liquid must be expelled by consolidation, usually caused by an overburden. Because saltcake drains when stabilized, it is more subject to potential drying at the surface as a result of water evaporation.

- Status. Modeling of the water retention properties of saltcake and sludge waste was completed and documented in September 1995 (Simmons 1995). Water retention modeling for the Ferrocyanide Safety Program has been completed. However, additional saltcake modeling continues for the Organic Safety Program. 


\subsection{CHEMICAL REACTION STUDIES}

"The schedule for the program on study of the chemical properties and explosive behavior of the waste in these tanks is indefinite and does not reflect the urgent need for a comprehensive and definitive assessment of the probability of a violent chemical reaction. The study should be extended to other metallic compounds of ferrocyanide that are known or believed to be present in the tanks, so that conclusions can be generalized as to the range of temperature and other properties needed for a rapid chemical reaction with sodium nitrate."

Chemical reaction studies on ferrocyanide waste simulants have been conducted by Westinghouse Hanford Company, FAI, PNNL, and Los Alamos National Laboratory (LANL). Only the PNNL program was on-going during this quarter; all the other programs have been completed. Both Westinghouse Hanford Company and PNNL have produced flowsheet simulant materials for testing and characterization. Earlier, FAI conducted adiabatic calorimetry and propagation tests on these same flowsheet materials and on stoichiometric mixtures of pure sodium nickel ferrocyanide and sodium nitrate/nitrite. The test program at LANL evaluated the sensitivity of ferrocyanide reactions to shock, friction, and thermal aging (Cady 1993) and was completed in FY 1993.

\subsubsection{Chemical Reaction Studies at Pacific Northwest National Laboratory}

Chemical reaction studies are nearing completion at PNNL using flowsheet simulant materials. Waste studies addressing DNFSB Recommendation 90-7.5 have been conducted to determine the following: (1) aging effects (hydrolysis and radiolysis) from more than $35 \mathrm{yr}$ of storage in the tanks; (2) reaction kinetics and properties of various mixtures of ferrocyanide with sodium nitrate and/or sodium nitrite; (3) comparison of waste simulant and actual waste properties; and (4) modeling calculations to predict the moisture-retaining capability of ferrocyanide waste in a typical tank system. All of these tasks are complete except for the aging effects studies.

\section{- Progress During Reporting Period.}

Aging Studies. Experiments to test the reproducibility of aging results were completed this quarter. In the reproducibility experiments, vessel/gamma access tube combinations were systematically varied to investigate the effects of vessel, gamma access tube, and sample preparation and analysis techniques.

Experiments were all conducted with the In-Farm waste simulant in $2 M \mathrm{NaOH}$ at $90{ }^{\circ} \mathrm{C}$ and $1 \times 10^{5} \mathrm{rad} / \mathrm{h}$ for $12 \mathrm{~d}$, except for controls that were not irradiated. These conditions duplicate conditions for Experiment $\mathrm{H}-1$, the first aging experiment. Ammonia production data for Experiment $\mathrm{H}-1$ and the reproducibility experiments are shown in Figure 3-1. The concentrations plotted are those observed in solution and do not take into account the amount of ammonia lost to radiolysis. Also shown are the least squares regression fit, assuming zero-order ammonia production, and the $95 \%$ confidence limits. 
Figure 3-1. Ammonia Production and Reproducibility in the Hydrolysis of In-Farm-1B Simulant in $25 \mathrm{~mL}$ of $2 \mathrm{M} \mathrm{NaOH}$ at $90^{\circ} \mathrm{C}$ and $1 \times 10^{\circ} \mathrm{rad} / \mathrm{h}$.

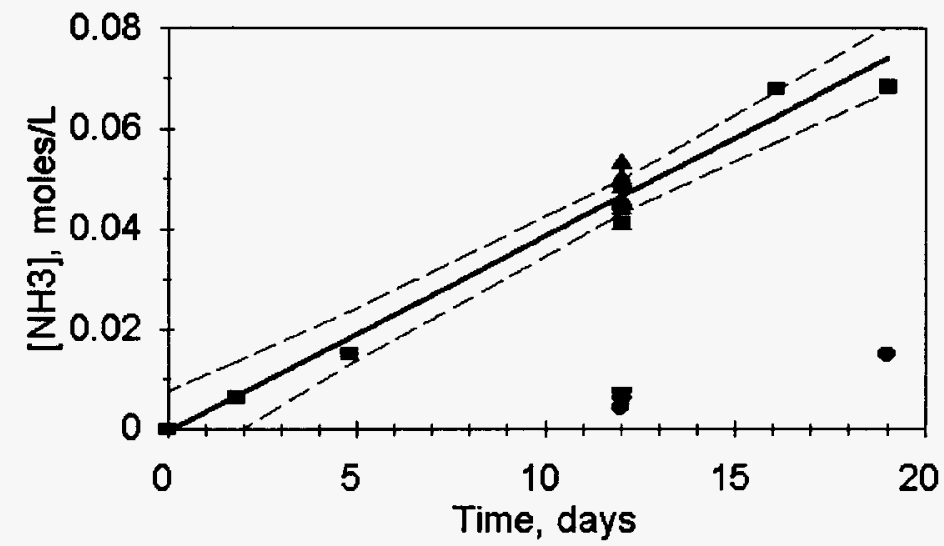

\begin{tabular}{lll}
\hline$--95 \%$ Confidence & - Regression & H1, Gamma \\
- Duplicates & $-\mathrm{H} 1$ Control & $\sim$ Dup. Control
\end{tabular}

The data have a percent-relative standard deviation of $8 \%$. The data show that, within the experimental error, the zero-order approximation adequately describes the global aging process, up to at least the approximately $80 \%$ aging that occurred in Experiment $\mathrm{H}-1$. The results of the reproducibility experiments also show that there was very little error associated with sample preparation and analysis. More error was introduced when different vessels were used in the same gamma tube than when the same vessel was used in different gamma tubes.

The relative sensitivity to vessel likely arises from slight differences in temperature control rather than variations in gamma dose rate or sample preparation and analysis. 
Atomic absorption (AA) analyses of reaction solutions aged under a variety of temperature and gamma dose rate conditions showed that both soluble iron and nickel species were present. FTIR was used to identify the soluble iron as $\mathrm{Fe}(\mathrm{CN})_{6}^{4}$ and soluble nickel as $\mathrm{Ni}(\mathrm{CN})_{4}^{-2}$ Concentrations determined by FTIR were nearly identical to the concentrations from AA, showing that essentially all of the soluble iron and nickel were present as the cyano complexes.

Quantification of these cyano species allowed a determination of the approximate cyanide balance. The sum of the moles of cyanide bound to nickel and iron using FTIR results, combined with the moles of ammonia measured, accounts for the starting cyanide (percent cyanide that was found ranges from $89-109 \%$ ) for the 11 samples analyzed (see Table 3-1). The amount of ammonia destroyed by radiolysis is not included in these calculations. The good mass balance shows that ammonia is an appropriate indicator of the extent of aging.

The final Aging Studies report was completed this quarter (Lilga et al. 1996). The report summarizes work on the Aging Studies Task from FY 1992 to FY 1996. Extensive experiments were conducted to determine how aging is affected by $\mathrm{pH}$, dose rate, and temperature.

The experiments showed that the rate of thermal ferrocyanide aging does not increase at higher $\mathrm{pH}$ when the $\mathrm{pH}$ exceeds nine (Lilga et al. 1996). The precipitation of sodium nickel ferrocyanide was done at slightly alkaline conditions $(\mathrm{pH}=8.0-10)$. However, the ferrocyanide tanks were used for a variety of waste management operations that exposed the tanks to alkaline waste (Anderson 1990). Review of the available historical $\mathrm{pH}$ and hydroxide data collected for the ferrocyanide tanks shows that all the tanks had $\mathrm{pH}$ values greater than nine (Wodrich et al. 1992). Consequently, waste pH was not a limiting factor for ferrocyanide waste aging in Hanford Site tanks.

The results of experiments at various dose rates $\left(0\right.$ to $\left.10^{5} \mathrm{rad} / \mathrm{h}\right)$ were revealing since the rate of aging is only noticeably affected at the highest dose rate $\left(10^{5} \mathrm{rad} / \mathrm{h}\right)$. There was little impact from dose rate observed for dose rates between 0 and $1,000 \mathrm{rad} / \mathrm{h}$; all the points essentially fall on the same curve. Dose rates in the ferrocyanide waste tanks were calculated to be in the $1,000 \mathrm{rad} / \mathrm{h}$ range, and none approached 10,000 rad/h (Parra 1994). Consequently, dose rates in the ferrocyanide tanks had only a second order effect on the rate of aging.

Experiments on waste simulants show that the rate of aging was strongly affected by temperature (Lilga et al. 1996). As shown in Table 3-2, the rate of aging increased dramatically with increasing temperature. The experiments show that the extent of ferrocyanide aging in Hanford Site tanks was primarily determined by the individual tank temperature histories. 
Table 3-1. Cyanide Mass Balance.

\begin{tabular}{|c|c|c|c|c|c|c|}
\hline $\begin{array}{c}\text { Sample } \\
\text { Number }\end{array}$ & $\begin{array}{c}\text { Total } \\
{[\mathrm{CN}]} \\
\text { Present } \\
\text { mol/L }\end{array}$ & $\begin{array}{c}{\left[\mathrm{NH}_{3}\right]} \\
\mathrm{mol} / \mathrm{L}\end{array}$ & $\begin{array}{c}{\left[\mathrm{Fe}(\mathrm{CN})_{6}^{4}\right]} \\
\mathrm{mol} / \mathrm{L}\end{array}$ & $\begin{array}{c}{\left[\mathrm{Ni}(\mathrm{CN})_{4}^{-2}\right]} \\
\mathrm{mol} / \mathrm{L}\end{array}$ & $\begin{array}{c}\text { Total } \\
{[\mathrm{CN}]} \\
\text { Found } \\
\mathrm{mol} / \mathrm{L}\end{array}$ & $\begin{array}{c}\% \\
\text { Found }\end{array}$ \\
\hline H1-C2 & 0.0996 & 0.0150 & 0.0154 & 0.0 & 0.1074 & 108 \\
\hline H1-S4 & 0.0996 & 0.0410 & 0.0385 & 0.00850 & 0.0981 & 99 \\
\hline H1-S6 & 0.0996 & 0.0684 & 0.0104 & 0.0212 & 0.1000 & 100 \\
\hline H4-C2 & 0.0996 & 0.0110 & 0.0160 & 0.0 & 0.1070 & 107 \\
\hline H4-S6 & 0.0996 & 0.0383 & 0.00605 & 0.00806 & 0.1068 & 107 \\
\hline H5-C2 & 0.0996 & 0.00910 & 0.0165 & 0.0 & 0.1081 & 109 \\
\hline H5-S5 & 0.0996 & 0.0152 & 0.0132 & 0.00210 & 0.1028 & 103 \\
\hline H10-C1 & 0.0960 & 0.00087 & 0.0155 & 0.0 & 0.0939 & 98 \\
\hline H10-S6 & 0.0960 & 0.0205 & 0.00390 & 0.00970 & 0.0827 & 86 \\
\hline H11-C2 & 0.1032 & 0.0413 & 0.0114 & 0.0 & 0.1097 & 106 \\
\hline H11-S2a & 0.1032 & 0.0375 & 0.00557 & 0.00716 & 0.0995 & 96 \\
\hline
\end{tabular}

Table 3-2. Aging Rates as a Function of Temperature for Waste Simulant Experiments.

\begin{tabular}{|c|c|}
\hline $\begin{array}{c}\text { Temperature } \\
{ }^{\circ} \mathrm{C}\left({ }^{\circ} \mathrm{F}\right)\end{array}$ & $\begin{array}{c}\text { Reaction Rate } \\
\mathrm{g} \mathrm{Na}_{2} \mathrm{NiFe}(\mathrm{CN})_{6} / 100 \mathrm{~g} \text { dry solids/yr }\end{array}$ \\
\hline $40(104)$ & 0.04 \\
\hline $50(122)$ & 0.19 \\
\hline $60(140)$ & 0.90 \\
\hline $70(158)$ & 3.9 \\
\hline $80(176)$ & 15.5 \\
\hline $90(194)$ & 57 \\
\hline
\end{tabular}

- Status. All work is complete for this task and DNFSB Recommendation 90-7.5 is closed. 


\subsubsection{Preparation and Characterization of Ferrocyanide Simulants}

Earlier in the Ferrocyanide Safety Program, various ferrocyanide waste simulants were prepared and analyzed to determine their chemical reaction properties as a function temperature and water present in the mixture. Other tests were conducted with pure sodium nickel ferrocyanide, a stoichiometric amount of oxidizer (sodium nitrate/nitrite), and water. These latter tests were conducted by FAI to define the margin of safety between the theoretical and experimental propagation limits for ferrocyanide. These tests are run in the FAI reactive systems screening tool. These tests and previous tests with simulants (along with analyses of actual tank waste samples, waste tank monitoring, and waste modeling), provide information to characterize with a large degree of conservatism the safety concerns relating to the ferrocyanide sludge originally added to 18 of the Hanford Site waste tanks.

- Status. A financial change request was approved the previous quarter that deleted further chemical reactivity work at FAI on the Ferrocyanide Safety Issue. Further work is not required because previous chemical reaction studies and results obtained by sampling nine of the ferrocyanide tanks show that the fuel value of ferrocyanide has degraded (aged) to levels too low to be of concern. No further work is planned in this area.

- Milestone Status.

- September 30, 1996. Complete FAI support for Ferrocyanide Safety Issue resolution and conclude chemical reactivity studies of chemical waste. This milestone was deleted by the financial change request approved last quarter.

\subsection{EMERGENCY RESPONSE PLANNING}

"The Board had recommended 'that an action plan be developed for the measures to be taken to neutralize the conditions that may be signaled by alarms.' Two types of measures are implied: actions to respond to unexpected degradation of a tank or its contents, and actions to be taken if an explosion were to occur. Your implementation plan stated that the current contingency plans ... will be reviewed and revised if needed.' We do not consider that this proposed implementation of the Board's recommendation is adequately responsive. It is recommended that a written action plan founded on demonstrated principles be prepared as soon as possible, that would respond to indications of onset of abnormal temperatures or other unusual conditions in a ferrocyanide-bearing tank, to counter any perceived growth in hazard. A separate emergency plan should be formulated and instituted, covering measures that would be taken in event of an explosion or other event leading to an airborne release of radioactive material from the tanks, and that would protect personnel both on and off the Hanford Site. The Board believes that even though it is considered that the probability is small that such an event will occur, prudence dictates that steps be taken at this time to prepare the means to mitigate the unacceptable results that could ensue." 
The original Action Plan for Response to Abnormal Conditions in Hanford Radioactive Waste Tanks Containing Ferrocyanide (Cash and Thurman 1991) was prepared in response to DNFSB Recommendation 90-7.6. The plan describes the steps to be taken if a temperature-increase trend above the tank temperature baseline is measured in any of the ferrocyanide tanks. The document was revised to include the monitoring criteria and responses for abnormal levels of flammable and toxic gases, as well as the reporting requirements, if established criteria are exceeded (Cash and Thurman 1992). The second revision of the plan was released in June 1994 (Fowler 1994).

The Tank Farm Stabilization Plan For Emergency Response, WHC-SD-PRP-TI-001, Revision 0 (WHC 1991) was issued in March 1991. If a radioactive release from a ferrocyanide tank were to occur, it would be detected by one or more radiation monitoring systems. Significant airborne or ground surface releases that spread beyond the immediate tank or tank farm would be detected by the tank farm area radiation detectors. These monitoring systems are on all tank farms. An emergency involving an underground radioactive waste storage tank is a unique event with potentially serious consequences both onsite and offsite. The stabilization plan provides quick, preplanned actions that can be used to stabilize an emergency event at an underground radioactive waste storage tank.

All actions with respect to emergency planning, emergency event recognition, protective action recommendations, and emergency response procedures have been completed. Further revisions and occasional validation exercises will be accomplished as part of the normal Westinghouse Hanford Company and DOE emergency planning efforts. No further reporting on these issues is planned, and this part of DNFSB Recommendation 90-7.6 is considered complete and closed.

DOE considers this recommendation to be closed with the provisos that the abnormal conditions response plan and emergency plans are reviewed on a periodic basis and revised and updated as required to incorporate any additional controls determined appropriate by the ongoing Waste Tank Safety Program investigations. The Action Plan for Response to Abnormal Conditions in Hanford Site Radioactive Waste Tanks Containing Ferrocyanide was updated and released in June 1994, (Fowler 1994); and validation exercises for various waste tank accident scenarios are conducted periodically (exercises for the tank farms are conducted every two years).

- Status. As noted in previous reports, all of the planned milestones for this task have been completed. 
WHC-EP-0474-21

This page intentionally left blank. 


\subsection{IMPLEMENTATION OF THE WYDEN AMENDMENT}

The Wyden Amendment (Public Law 101-510, 1990) requires that:

"...the Secretary of Energy shall identify which single-shelled or double-shelled high-level nuclear waste tanks at the Hanford Nuclear Reservation, Richland, Washington, may have a serious potential for release of high-level waste due to uncontrolled increases of temperature or pressure. After completing such identification, the Secretary shall determine whether continuous monitoring is being carried out to detect a release or excessive temperature or pressure at each tank so identified. If such monitoring is not being carried out, as soon as practicable the Secretary shall install such monitoring, but only if a type of monitoring that does not itself increase the danger of a release can be installed."

\subsection{THE WATCH LIST}

In March 1989, using process knowledge, process records, transfer records, and log books, Westinghouse Hanford Company identified 22 Hanford Site tanks as potentially containing $1,000 \mathrm{~g}$-mol (211 kg or $465 \mathrm{lb}$ ) or more of ferrocyanide as the $\mathrm{Fe}(\mathrm{CN})_{6}^{4}$ anion (Nguyen 1989). To avert possible injury to personnel and damage to the facility or environment, strict controls were identified for these and other tanks with safety issues. These controls were described in Operating Specifications for Watch List Tanks, OSD-T-151-00030, Revision 0 (WHC 1990). Tanks identified by this document have been commonly referred to as Watch List tanks (see WHC 1996 for latest revision). Two additional ferrocyanide tanks were identified in January 1991 (Borsheim and Cash 1991), increasing the total number of ferrocyanide tanks to 24 .

In November 1990, the Wyden Amendment (Public Law 101-510, 1990) was enacted. This law required the identification of Hanford Site tanks that may have a serious potential for release of high-level waste. In February 1991, the 24 ferrocyanide tanks were among the tanks identified (Harmon 1991), and were included in the subsequent July 1991 report to Congress that responded to the Wyden Amendment (Watkins 1991). However, re-examination of the historical records indicated that six of the 24 tanks did not contain the requisite $1,000 \mathrm{~g}$-mol of ferrocyanide (Borsheim and Simpson 1991). Therefore, these six tanks should not have been included on the Watch List or been identified in the response to the Wyden Amendment. The six tanks were subsequently removed from the Watch List (Anttonen 1993, Sheridan 1994b). Since these tanks do not contain greater than 8 wt\% $\mathrm{Na}_{2} \mathrm{NiFe}(\mathrm{CN})_{6}$, they should not be on the Watch List for this reason also.

As part of the overall safety screening module being conducted by Westinghouse Hanford Company Tank Waste Remediation System, all of the Hanford Site SSTs will be core-sampled and characterized. Fourteen ferrocyanide tanks are currently on the Watch List, and no additional ferrocyanide tanks are expected to be added to the Watch List. 
Work conducted since 1991 on ferrocyanide reactions has resulted in a change of the criterion used for placing ferrocyanide tanks on the Watch List. The 1,000 g-mol inventory criterion has now been replaced with a fuel concentration criterion of $115 \mathrm{cal} / \mathrm{g}$ of dry sample (this is an energy equivalent to a concentration of $8 \mathrm{wt} \% \mathrm{Na}_{2} \mathrm{NiFe}(\mathrm{CN})_{6}$ in the waste). This fuel concentration criterion more accurately reflects the risk associated with ferrocyanide tanks. Ferrocyanide tanks with concentrations less than an energy equivalent of $8 \mathrm{wt} \%$ $\mathrm{Na}_{2} \mathrm{NiFe}(\mathrm{CN})_{6}$ cannot support a propagating reaction, and are categorized as safe. Detailed rationale for the $115 \mathrm{cal} / \mathrm{g}$ of dry fuel concentration criterion is presented in Ferrocyanide Safety Program: Safety Criteria for Ferrocyanide Watch list Tanks, WHC-EP-0691 (Postma et al. 1994).

Core sampling and characterization efforts will determine the ferrocyanide concentration for those tanks that bound aging (see Sections 2.2 and 3.4). After adequate characterization, if these tanks contain concentrations less than $8 \mathrm{wt} \% \mathrm{Na}_{2} \mathrm{NiFe}(\mathrm{CN})_{6}$ (i.e., the fuel value of the maximum concentration is less than $115 \mathrm{cal} / \mathrm{g}$ ), then a request will be made by Westinghouse Hanford Company for DOE concurrence to remove all of the ferrocyanide tanks from the Watch List.

Since some sample bias and analytical error are unavoidable, confidence intervals have been established to specify when it is appropriate to conclude that a ferrocyanide tank contains concentrations less than an energy equivalent of $8 \mathrm{wt} \% \mathrm{Na} \mathrm{N}_{2} \mathrm{NiFe}(\mathrm{CN})_{6}$. An $80 \%$ confidence interval was chosen for tanks with a fuel concentration of $8 \mathrm{wt} \% \mathrm{Na}_{2} \mathrm{NiFe}(\mathrm{CN})_{6}$. That is, if five ferrocyanide tanks contain exactly an energy equivalent of $8 \mathrm{wt} \% \mathrm{Na}_{2} \mathrm{NiFe}(\mathrm{CN})_{6}$, statistically, four tanks would remain on the Watch List and one tank would be removed. The possibility of removing a ferrocyanide tank from the Watch List decreases substantially as the fuel concentration increases. The confidence intervals increase to $95 \%$ and $99 \%$ at $\mathrm{Na}_{2} \mathrm{NiFe}(\mathrm{CN})_{6}$ concentrations of $12 \%$ and $15 \mathrm{wt} \%$, respectively. Detailed discussions on how sample bias and analytical error are factored into determining the actual fuel concentrations in a ferrocyanide tank are given in the Ferrocyanide DQO (Meacham et al. 1995).

- Planned Work To Complete Program. DOE-RL has approved removal of the four C-Farm ferrocyanide tanks from the Watch List. Documentation is being identified to make the change and the required actions will be transmitted to DOE-RL. As indicated earlier, submittal of the final technical basis safety document to DOE-RL on July 3, 1996, has provided the basis for and resolution of the Ferrocyanide Safety Issue (Meacham et al. 1996) and removal of the final 14 ferrocyanide tanks from the Watch List.

Work on the Ferrocyanide Safety Program is continuing to draw to a rapid close and sampling of additional tanks is not necessary to resolve the safety issue. A final report on the aging test program at PNNL was completed. All six parts of DNFSB Recommendation 90-7 have been adequately addressed, and in March 1996 a letter was transmitted to the Chairman of the DNFSB by DOE Headquarters, that requested closure of the recommendation (Guimond 1996). 
- Milestones.

- January 31, 1996. Westinghouse Hanford Company issues documentation supporting safety issue resolution for the four C-Farm tanks and recommends their removal from the Wyden Amendment Watch List (Public Law 101-510, 1990). The Assessment of the Potential for Ferrocyanide Propagating Reaction Accidents, WHC-SD-WM-SARR-038, Revision 0, was transmitted to DOE-RL as scheduled (Bacon 1996a, Grigsby et al. 1996a). All four C-Farm tanks were sampled earlier and data interpretation reports were completed for these tanks.

The report was revised to incorporate informal comments received from DOE-RL and reissued with the same title as WHC-SD-WM-SARR-038, Revision 0A, (Grigsby et al. 1996b). The revised report was transmitted to DOE-RL on March 19,1996, with a letter requesting that the four C-Farm tanks be removed from the Watch List (Bacon 1996b). The report was subsequently forwarded to the DNFSB Staff on April 10, 1996 (Trine 1996).

- July 31, 1996. Westinghouse Hanford Company receives DOE approval to remove the four C-Farm ferrocyanide tanks from the Watch List. Approval was received from DOE-RL on June 25, 1996 to remove these tanks from the Watch List.

- March 31, 1997. Westinghouse Hanford Company prepares documentation to support removal of the last 14 ferrocyanide tanks from the Watch List and recommends final resolution of the Ferrocyanide Safety Issue. This milestone was accelerated to July 3, 1996, and the final safety document, WHC-SD-WM-SARR-038, Revision 1, (Meacham et al. 1996) was transmitted to DOE-RL on July 3, 1996 (Bacon 1996c).

- September 30, 1997. Westinghouse Hanford Company receives DOE approval to remove the remaining 14 ferrocyanide tanks from the Watch List and to declare the Ferrocyanide Safety Issue resolved. This action will complete the Ferrocyanide Safety Program. DOE-RL expects to complete this action by September 30, 1996.

\subsection{TEMPERATURE MONITORING}

The installation of temperature monitoring capabilities is discussed in Sections 3.1.2.1 and 3.2.2. Installation of instrument trees and continuous temperature monitoring are considered prudent waste management practices. Therefore, new instrument trees will be installed in 
ferrocyanide tanks, even though the ferrocyanide waste has aged and little fuel value remains. Instrument trees have been installed in all ferrocyanide tanks and are continuously monitored by TMACS.

- Status. This task is complete.

\subsection{PRESSURE MONITORING}

The ferrocyanide tanks were initially identified as having "a serious potential for release" and were placed on the Watch List because insufficient data were available on the probability for ferrocyanide-nitrate/nitrite reactions. Pressure monitoring instrumentation is not presently installed on the ferrocyanide tanks. It would take several years to install pressure monitoring instrumentation because of the capital project time cycle. Ferrocyanide waste has probably degraded (aged) significantly, and all of the tanks may now contain less than the $8 \mathrm{wt} \%$ $\mathrm{Na}_{2} \mathrm{NiFe}(\mathrm{CN})_{6}$ fuel concentration specified for the safe category (Postma et al. 1994a). This eliminates the need for continuous pressure monitoring for offgases from a ferrocyanide reaction.

The rationale for not installing pressure monitors in ferrocyanide tanks was prepared and submitted to DOE in July 1994 (Payne 1994a). Low gas generation rates (Fowler and Graves 1994) and the low potential for exothermic ferrocyanide reactions (Postma et al. 1994a) indicated that continuous pressure monitoring is not warranted.

- Planned Work For Subsequent Months. No additional work is planned in this area, because DOE has concurred that pressure monitoring is not required as stated in the revised Ferrocyanide Safety Issue Program Plan (O'Leary 1994). 


\subsection{PROGRAM SCHEDULES AND MILESTONES}

Schedules are presented in this section (see Figure 5-1). The schedules review milestones for FY 1994, through the expected end of the program in FY 1997. The sequence and anticipated completion dates of the major milestones leading to resolution of the Ferrocyanide Safety Issue are presented. Closure of DNFSB recommendations are indicated on the schedule as diamonds, and completion of interim milestones are indicated as triangles. The schedules are statused through June 30, 1996. 
Figure 5-1. Ferrocyanide Waste Tank Safety Schedule. (Sheet 1 of 2)

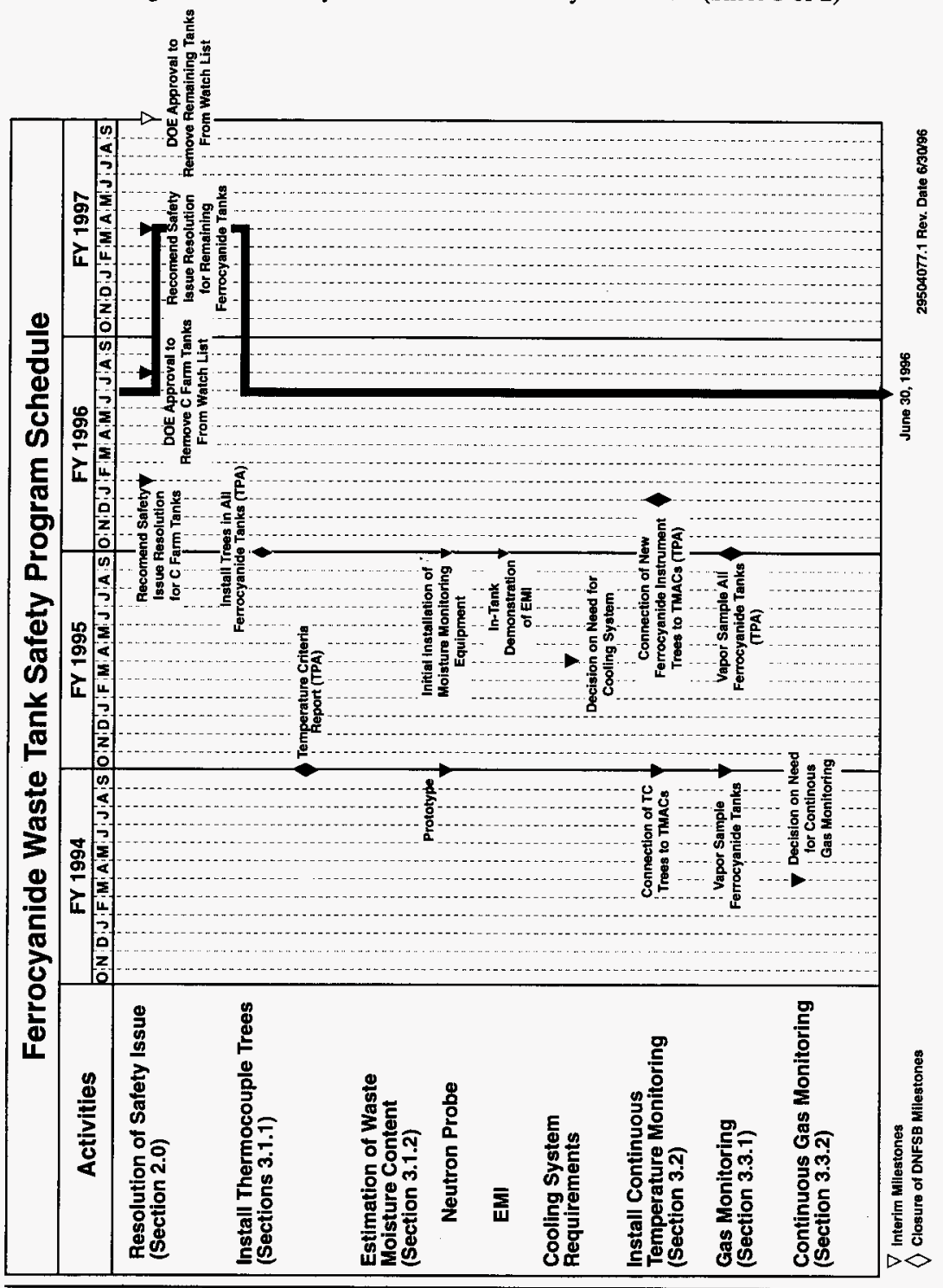


Figure 5-1. Ferrocyanide Waste Tank Safety Schedule. (Sheet 2 of 2)

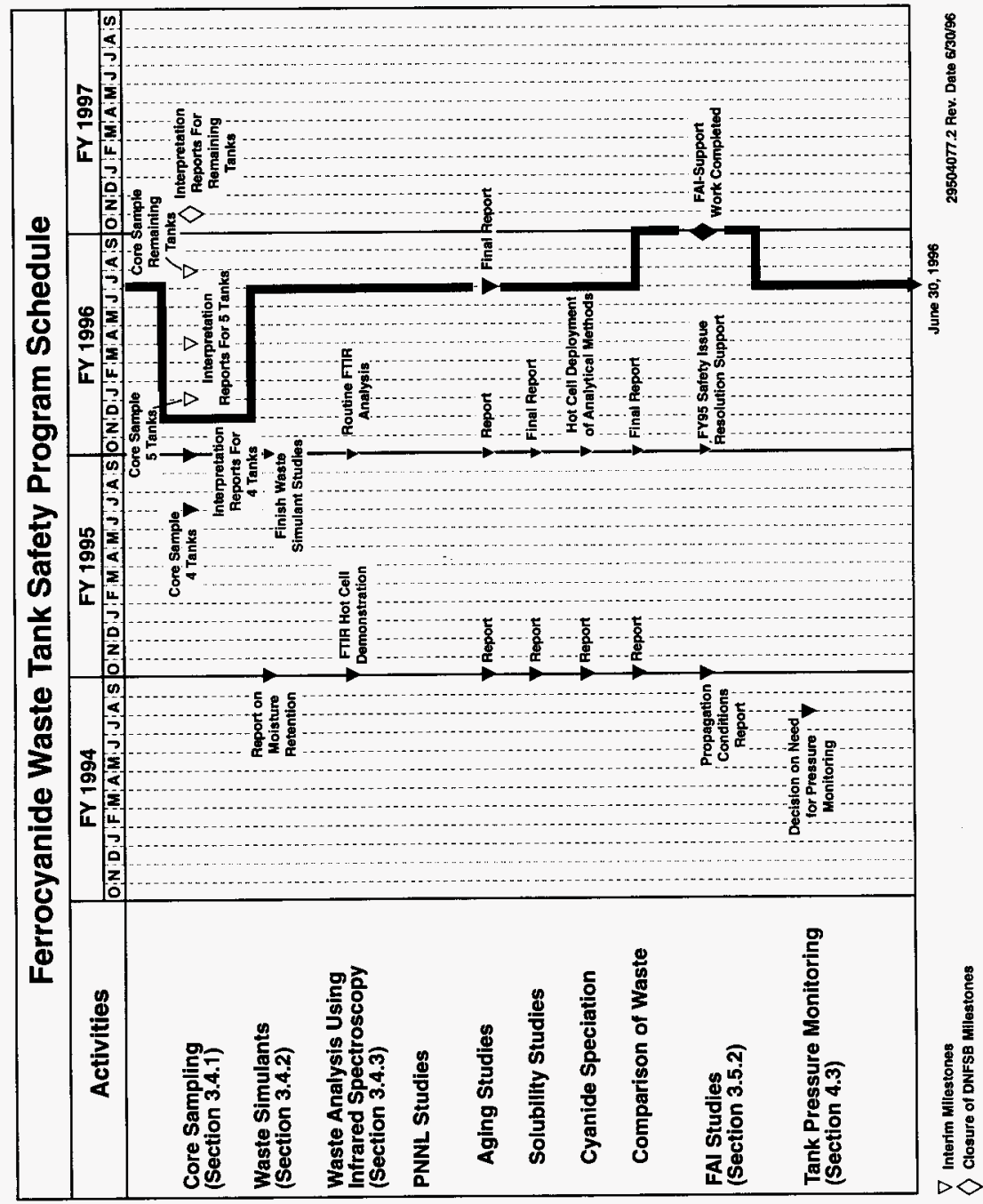


WHC-EP-0474-21

This page intentionally left blank. 


\subsection{REFERENCES}

Anderson, J. D., 1990, A History of the 200 Area Tank Farms, WHC-MR-0132, Westinghouse Hanford Company, Richland, Washington.

Anttonen, J. H., 1993, Resolution of Unreviewed Safety Question (USQ) for Four Ferrocyanide Tanks, (letter 9304645B/93-CAB-223 to T. M. Anderson, President, Westinghouse Hanford Company, July 9), U.S. Department of Energy, Richland Operations Office, Richland, Washington.

Bacon, R. F., 1996a, Ferrocyanide Safety Program: Request for Removal of 14 Ferrocyanide Tanks from the Watch List and Resolution of the Ferrocyanide Safety Issue, (letter 9652982 to J. E. Kinzer, DOE-RL, July 3), Westinghouse Hanford Company, Richland, Washington.

Bacon, R. F., 1996b, Ferrocyanide Safety Program: Request for Resolution of the Ferrocyanide Safety Issue and Deletion from the Watch List for Four C-Farm Tanks, (letter 9651198 to J. E. Kinzer, DOE-RL, March 19), Westinghouse Hanford Company, Richland, Washington.

Bacon, R. F., 1996c, Ferrocyanide Safety Program: Request for Removal of 14 Ferrocyanide Tanks from the Watch List and Resolution of the Ferrocyanide Safety Issue, (letter 9652982 to J. W. Kinzer, DOE-RL, July 3), Westinghouse Hanford Company, Richland, Washington.

Benar, C. J., 1996a, 45-Day Safety Screening Results for Tank 241-BY-104, Rotary Mode [in Push Mode] Cores 116 and 117, WHC-SD-WM-DP-164, Rev. 0, Westinghouse Hanford Company, Richland, Washington.

Benar, C. J., 1996b, Final Report for Tank 241-BY-104, Rotary Mode Cores [in Push Mode] 116 and 117, WHC-SD-WM-DP-164, Rev. 1, Westinghouse Hanford Company, Richland, Washington.

Borsheim, G. L., and R. J. Cash, 1991, Unusual Occurrence - Addition of Two Tanks to List of Unreviewed Safety Question Tanks Containing Ferrocyanide, WHC-91-0096-TFARM, February 13, Westinghouse Hanford Company, Richland, Washington.

Borsheim, G. L., and B. C. Simpson, 1991, An Assessment of the Inventories of Ferrocyanide Watch List Tanks, WHC-SD-WM-EP-133, Rev. 0, Westinghouse Hanford Company, Richland, Washington. 
Bussell, J. H., 1992, Engineering Evaluation of Thermocouples in Ferrocyanide Watch List Tanks, WHC-SD-WM-ER-134, Rev. 0 and Rev. 0A, Westinghouse Hanford Company, Richland, Washington.

Cady, H. H., 1993, Evaluation of Ferrocyanide/Nitrate Explosive Hazard, LA-12589-MS, Los Alamos National Laboratory, Los Alamos, New Mexico.

Cash, R. J., 1991, Implementation Plan for the Defense Nuclear Facilities Safety Board Recommendation 90-7, WHC-EP-0415, Rev. 0, Westinghouse Hanford Company, Richland, Washington.

Cash, R. J., and J. E. Meacham, 1996, Quarterly Report on the Ferrocyanide Safety Program for the Period Ending March 31, 1996, WHC-EP-0474-20, Westinghouse Hanford Company, Richland, Washington.

Cash, R. J., and J. M. Thurman, 1991, Action Plan for Response to Abnormal Conditions in Hanford Site Radioactive Waste Tanks Containing Ferrocyanide, EP-0407, Rev. 0, Westinghouse Hanford Company, Richland, Washington.

Cash, R. J., and J. M. Thurman, 1992, Action Plan for Response to Abnormal Conditions in Hanford Site Radioactive Waste Tanks Containing Ferrocyanide, EP-0407, Rev. 1, Westinghouse Hanford Company, Richland, Washington.

Claybrook, S. W., and S. A. Wood, 1994, Organic Evaporation in Waste Tank C-103, WHC-SD-WM-ER-344, Rev. 0, Westinghouse Hanford Company, Richland, Washington.

Crowe, R. D., M. Kummerer, and A. K. Postma, 1993, Estimation of Heat Load in Waste Tanks Using Average Vapor Space Temperatures, WHC-EP-0709, Rev. 0, Westinghouse Hanford Company, Richland, Washington.

Crowe, R. D., and W. D. Wittekind, 1995, Ferrocyanide Safety Program: In-Tank Application of Electromagnetic Induction (EMI) Moisture Measurements - FY 1995 Report, WHC-SD-WM-ER-520, Rev. 0, Westinghouse Hanford Company, Richland, Washington.

Deaton, D. E., 1990, Unusual Occurrence - Unreviewed Safety Questions Regarding Tanks Containing Ferrocyanide, WHC-90-B003-R1 (Update 10-22-90), Westinghouse Hanford Company, Richland, Washington.

Dukelow, G. T., J. W. Hunt, H. Babad, and J. E. Meacham, 1995, Tank Safety Screening Data Quality Objective, WHC-SD-WM-SP-004, Rev. 2, Westinghouse Hanford Company, Richland, Washington. 
Dickinson, D. R., J. M. McLaren, G. L. Borsheim, and M. D. Crippen, 1993, Ferrocyanide Safety Program: Credibility of Drying Out Ferrocyanide Tank Waste by Hot Spots, WHC-EP-0648, Rev. 0, Westinghouse Hanford Company, Richland, Washington.

DOE, 1987, Final Environmental Impact Statement, Disposal of Hanford Defense High-Level, Transuranic and Tank Waste, Hanford Site, Richland, Washington, DOE/EIS-0113, Vol. 1 through 5, U.S. Department of Energy, Washington, D.C.

DOE, 1994a, Recommendation 93-5 Implementation Plan, DOE/RL 94-0001, U.S. Department of Energy, Richland Operations Office, Richland, Washington.

DOE, 1994b, Program Plan for Resolution of the Ferrocyanide Waste Tank Safety Issue at the Hanford Site, DOE/RL-94-110, Revision 1, U.S. Department of Energy, Richland Operations Office, Richland, Washington.

Douglas, J. G., and F. R. Reich, 1995, Summary Report of FY 1995 Raman Spectroscopy Technology Development, WHC-SD-TD-TI-003, Rev. 0, Westinghouse Hanford Company, Richland, Washington.

Dukelow, G. T., J. W. Hunt, H. Babad, and J. E. Meacham, 1995, Tank Safety Screening Data Quality Objective, WHC-SD-WM-SP-004, Rev. 2, Westinghouse Hanford Company, Richland, Washington.

Epstein, M., H. K. Fauske, M. D. Crippen, D. R. Dickinson, J. D. McCormack, R. J. Cash, J. E. Meacham, and C. S. Simmons, 1994, Ferrocyanide Safety Program: An Assessment of the Possibility of Ferrocyanide Sludge Dryout, WHC-EP-0816, Rev. 0, Westinghouse Hanford Company, Richland, Washington.

Fauske, H. K., 1996, Assessment of Chemical Vulnerabilities in the Hanford High-Level Waste Tanks, WHC-SD-WM-ER-543, Rev. 0, Westinghouse Hanford Company, Richland, Washington.

FR, 1990, "Implementation Plan for Recommendation 90-3 at the Department of Energy's Hanford Site, Washington, " Federal Register, Defense Nuclear Facilities Safety Board Recommendation 90-7, Vol. 55, No. 202, pp. 42243 - 42244.

Finfrock, S. H., H. Toffer, and W. T. Watson, 1994, Potential Tank Waste Material Anomalies Located Near the Liquid Observation Wells: Model Predicted Responses of a Neutron Moisture Detection System, WHC-EP-0809, Westinghouse Hanford Company, Richland, Washington.

Fowler, K. D., 1994, Action Plan for Response to Abnormal Conditions in Hanford Site Radioactive Waste Tanks Containing Ferrocyanide, WHC-EP-0407, Rev. 2, Westinghouse Hanford Company, Richland, Washington. 
Fowler, K. D., and R. D. Graves, 1994, Decision Analysis for Continuous Cover Gas Monitoring of Ferrocyanide Watch List Tanks, WHC-EP-0743, Rev. 0, Westinghouse Hanford Company, Richland, Washington.

Gerton, R. E., 1994, Environmental Assessment (EA) and Finding of No Significant Impact (FONSI) for the Waste Tank Safety Program at the Hanford Site, (DOE/EA-0915), (letter 9402034B/94-SST-053 to President, Westinghouse Hanford Company, March 8), U.S. Department of Energy, Richland, Washington.

Grigsby, J. M., A. K. Postma, R. J. Cash, J. E. Meacham, M. A. Lilga, H. K. Fauske, and M. Epstein, 1996a, Assessment of the Potential for Ferrocyanide Propagating Reaction Accidents, WHC-SD-WM-SARR-038, Rev. 0, Westinghouse Hanford Company, Richland, Washington.

Grigsby, J. M., A. K. Postma, R. J. Cash, J. E. Meacham, M. A. Lilga, H. K. Fauske, and M. Epstein, 1996b, Assessment of the Potential for Ferrocyanide Propagating Reaction Accidents, WHC-SD-WM-SARR-038, Rev. 0A, Westinghouse Hanford Company, Richland, Washington.

Grigsby, J. M., D. B. Bechtold, G. L. Borsheim, M. D. Crippen, D. R. Dickinson, G. L. Fox, D. W. Jeppson, M. Kummerer, J. M. McLaren, J. D. McCormack, A. Padilla, B. C. Simpson, and D. D. Stepnewski, 1992, Ferrocyanide Waste Tank Hazard Assessment--Interim Report, WHC-SD-WM-RPT-032, Rev. 1, Westinghouse Hanford Company, Richland, Washington.

Guimond, R. J., 1996, [Closure of Defense Nuclear Facilities Safety Board Recommendation 90-7), (letter to J. T. Conway, Chairman, DNFSB, March 13), U.S. Department of Energy, Washington, D.C.

Harmon, H. D., 1991, Safery Measures for Waste Tanks at Hanford Site, Richland, Washington, (letter 9059124.1 to R. E. Gerton, DOE-RL, February 8), Westinghouse Hanford Company, Richland, Washington.

Kinzer, J. E., 1996, Authorization to Remove Four Ferrocyanide Tanks, 241-C-108, 241-C-109, 241-C-111, and 241-C-112 from the Watch List, (letter 9601578B/ 96-WSD-116 to A. L. Trego, President, Westinghouse Hanford Company, June 25), U.S. Department of Energy, Richland Operations Office, Richland, Washington.

Kress, T., K. Bandyopadhyay, P. d'Entremont, S. Slezak, and M. Reich, 1990, Risk of a Ferrocyanide Explosion in the Hanford Waste Tank Farm, (memorandum to John Tseng, DOE-HQ, September 20), Ad Hoc Task Force formed by U.S. Department of Energy to evaluate the ferrocyanide safety concerns at the Hanford Site, Oak Ridge National Laboratory, Oak Ridge, Tennessee. 
Lilga, M. A., R. T. Hallen, E. V. Alderson, M. O. Hogan, T. L. Hubler, G. L. Jones, D. J. Kowalski, M. R. Lumetta, W. F. Riemath, R. A. Romine, G. F. Schiefelbein, and M. R. Telander, 1996, Ferrocyanide Safety Project: Ferrocyanide Aging Studies Final Report, PNNL-11211, Pacific-Northwest National Laboratory, Richland, Washington.

Lipke, E. J., 1995, Ferrocyanide Safety Program: Completion of Milestone Report on Tank Moisture Data Interpretation Computer Program, (letter 9554603 to R. E. Gerton, DOE-RI, August 30), Westinghouse Hanford Company, Richland, Washington.

McLaren, J. M., 1993, Ferrocyanide Safety Program: Updated Thermal Analysis Model for Ferrocyanide Tanks with Application to Tank 241-BY-104, WHC-EP-0669, Rev. 0, Westinghouse Hanford Company, Richland Washington.

Mclaren, J. M., 1994a, Ferrocyanide Safety Program: Thermal Analysis of Ferrocyanide Tanks, Group I, WHC-EP-0729, Rev. 0, Westinghouse Hanford Company, Richland, Washington.

McLaren, J. M., 1994b, Ferrocyanide Safety Program: Thermal Analysis of Ferrocyanide Watch List Tanks, Group II, WHC-EP-0794, Rev. 0, Westinghouse Hanford Company, Richland, Washington.

Meacham, J. E., H. Babad, and H. Toffer, 1993, Moisture Monitoring of Ferrocyanide Tanks: An Evaluation of Methods and Tools, WHC-EP-0658, Rev. 0, Westinghouse Hanford Company, Richland, Washington.

Meacham, J. E., R. J. Cash, B. A. Pulsipher, and G. Chen, 1995, Data Requirements for the Ferrocyanide Safety Issue Developed Through the Data Quality Objectives Process, WHC-SD-WM-DQO-007, Rev. 1, Westinghouse Hanford Company, Richland, Washington.

Meacham, J. E., R. J. Cash, D. R. Dickinson, F. R. Reich, J. M. Grigsby, A. K. Postma, and M. A. Lilga, 1996, Assessment of the Potential for Ferrocyanide Propagating Reaction Accidents, WHC-SD-WM-SARR-038, Rev. 1, Westinghouse Hanford Company, Richland, Washington.

Nguyen, D. M., 1989, Data Analysis of Conditions in Single-Shell Tanks Suspected of Containing Ferrocyanide, (internal memorandum 13314-89-025 to N. W. Kirch, March 2), Westinghouse Hanford Company, Richland, Washington.

O'Leary, H. R., 1994, [Transmittal of "Program Plan for Evaluation of the Ferrocyanide Waste Tank Safety issue at the Hanford Site, "DOE/RL-94-110], (letter to J. T. Conway, Chairman, Defense Nuclear Facilities Safety Board, December 2), U.S. Department of Energy, Washington, D.C. 
Parra, S. A., 1994, Integrated Beta and Gamma Radiation Dose Calculations for Ferrocyanide Waste Tanks, WHC-SD-WM-TI-634, Rev. 0, Westinghouse Hanford Company, Richland, Washington. [July 1994]

Payne, M. A., 1994a, Ferrocyanide Safety Program: Continuous Pressure Monitoring in Ferrocyanide Watch List Tanks, (letter 9455175 to R. E. Gerton, DOE-RL, July 29), Westinghouse Hanford Company, Richland, Washington.

Payne, M. A., 1994b, Ferrocyanide Safery Program: Transmittal of General Accounting Office Closeout Report, (letter 9454280 to R. E. Gerton, DOE-RL, June 16), Westinghouse Hanford Company, Richland, Washington.

Peach, J. D., 1990, Consequences of Explosion of Hanford's Single-Shell Tanks are Understated, (letter B-241479 to M. Synar, Chairman, Environment, Energy, and Natural Resources Subcommittee, Committee on Government Operations, House of Representatives, October 10), GAO/RCED-91-34, U.S. General Accounting Office, Washington, D.C.

Postma, A. K., J. E. Meacham, G. S. Barney, G. L. Borsheim, R. J. Cash, M. D. Crippen, D. R. Dickinson, J. M. Grigsby, D. W. Jeppson, M. Kummerer, J. M. McLaren, C. S. Simmons, and B. C. Simpson, 1994a, Ferrocyanide Safety Program: Safety Criteria for Ferrocyanide Watch List Tanks, WHC-EP-0691, Westinghouse Hanford Company, Richland, Washington.

Postma, A. K., D. B. Bechtold, G. L. Borsheim, J. M. Grigsby, R. L. Guthrie, M. Kummerer, M. G. Plys, and D. A. Turner, 1994b, Safety Analysis of Exothermic Reaction Hazards Associated with the Organic Liquid Layer in Tank 241-C-103, WHC-SD-WM-SARR-001, Rev. 0, Westinghouse Hanford Company, Richland, Washington.

Public Law 101-510, Section 3137, 1990, Safety Measures for Waste Tanks at Hanford Nuclear Reservation, U.S. Congress, Washington, D.C. [Also referred to as the Wyden Amendment]

Rebagay, T. V., R. J. Cash, D. A. Dodd, C. T. Narquis, F. R. Reich, and W. D. Winkelman, 1995, Remote Characterization of Mixed Waste by Fourier Transform Infrared Spectroscopy, WHC-SD-WM-RPT-192, Rev. 0, Westinghouse Hanford Company, Richland, Washington.

Reich, F. R., R. E. Johnson, B. L. Philipp, J. B. Duncan, and G. L. Schutzenhofer, 1994, Summary of Fiscal Year 1994 Near-Infrared Spectroscopy Moisture Sensing Activities, WHC-EP-0839, Westinghouse Hanford Company, Richland, Washington. 
Reich, F. R., T. V. Rebagay, D. A. Dodd, T. Lopez, and J. K. Watts, 1995, Summary of FY 1995 NIR Moisture Measurement Development and Implementation Activities, WHC-SD-WM-RPT-191, Rev, 0, Westinghouse Hanford Company, Richland, Washington.

Schreiber, R. D., 1996, Final Report for Tank 241-BY-110 Rotary Mode Cores 92, 95, 101, 103, 106, 107, 109, 96, and 113, WHC-SD-WM-DP-153, Rev. 1, Westinghouse Hanford Company, Richland, Washington.

Sheridan, T. R., 1994a, Closure of the Ferrocyanide Unreviewed Safety Question, (letter 9401180/94-SST-052 to A. L. Trego, President, Westinghouse Hanford Company, March 4), U.S. Department of Energy, Richland Operations Office, Richland, Washington.

Sheridan, T. R., 1994b, Approval to Remove Two Ferrocyanide Tanks, 241-BX-102 and 241-BX-106, from the Watch List, (letter 9406684/94-SST-205 to A. L. Trego, President, Westinghouse Hanford Company, November 17), U.S. Department of Energy, Richland Operations Office, Richland, Washington.

Simmons, C. S., 1995, Modeling Water Retention of Tank Waste, PNL-10831, Pacific Northwest Laboratory, Richland, Washington.

Simpson, B. C., and D. J. McCain, 1996, Historical Model Evaluation Data Requirements, WHC-SD-WM-DQO-018, Rev. 1, Westinghouse Hanford Company, Richland, Washington.

Sloat, R. J., 1954, TBP Plant Nickel Ferrocyanide Scavenging Flowsheet, HW-30399, General Electric Company, Richland, Washington.

Sloat, R. J., 1955, In-Farm Scavenging Operating Procedure and Control Data, HW-38955, General electric Company, Richland, Washington.

Smith, D. A., 1986, Single-Shell Tank Isolation Safety Analysis Report, SD-WM-SAR-006, Rev. 2, Westinghouse Hanford Company, Richland, Washington.

Trine, S. L., 1996, Document Provided to Defense Nuclear Facilities Safety Board (DNFSB), (letter 96-PAD-079 to R. Tontodonato, DNFSB, April 10), U.S. Department of Energy, Richland Operations Office, Richland, Washington.

Wagoner, J. D., 1993, Approval of Hanford Site Tank Farm Facilities Interim Safety Basis, (letter 93-TOB-209 to T. M. Anderson, President, Westinghouse Hanford Company, November 18), U.S. Department of Energy, Richland Operations Office, Richland, Washington. 
Watkins, J. D., 1991, Report to United States Congress on Waste Tank Safety Issues at the Hanford Site, (letter to D. Quayle, President of the Senate, July 16), U.S. Department of Energy, Washington, D.C.

Watson, W. T., 1993, Proof of Principle Report for In-Tank Moisture Monitoring Using an Active Neutron Probe, WHC-EP-0695, Westinghouse Hanford Company, Richland, Washington.

WHC, 1990, Operating Specifications for Watch List Tanks, OSD-T-151-00030, Revision 0, Westinghouse Hanford Company, Richland, Washington.

WHC, 1991, Tank Farm Stabilization Plan for Emergency Ressponse, WHC-SD-PRP-TI-001, Rev. 0, Westinghouse Hanford Company, Richland, Washington.

WHC, 1996, Operating Specifications for Watch List Tanks, OSD-T-151-00030, Revision B-20, Westinghouse Hanford Company, Richland, Washington.

Wittekind, W. D., and R. D. Crowe, 1996, Electromagnetic Induction Probe Calibration for Electrical Conductivity Measurements and Moisture Content Determination of Hanford High Level Waste, WHC-SD-WM-ER-531, Rev. 0, Westinghouse Hanford Company, Richland, Washington.

Wodrich, D. D., G. S. Barney, G. L. Borsheim, D. L. Becker, W. C. Carlos, M. J. Klem, R. E. Van der Cook, and J. L. Ryan, 1992, Summary of Single-Shell Waste Tank Stability, WHC-EP-0347, Supplement, Westinghouse Hanford Company, Richland, Washington.

Wood, S. A., 1992, Gas Space Analysis For Tank C-109, WHC-SD-WM-ER-183, Rev. 0, Westinghouse Hanford Company, Richland, Washington. 
WHC-EP-0474-21

APPENDDX A

FERROCYANIDE TANK INFORMATION SUMMARY

A-1 
WHC-EP-0474-21

This page intentionally left blank. 
Table A-1. Summary of Contents and Status of Ferrocyanide Tanks."

\begin{tabular}{|c|c|c|c|c|c|c|}
\hline Tank & $\begin{array}{c}\text { Total waste } \\
\text { volume } \\
(1,000 \mathrm{~L})\end{array}$ & $\begin{array}{c}\mathrm{FeCN}^{\mathrm{b}} \\
(1,000 \mathrm{~g}-\mathrm{mol})\end{array}$ & $\begin{array}{l}\text { Heat load } \\
\left(^{(k W)^{c}}\right.\end{array}$ & $\begin{array}{l}\text { Maximum } \\
\text { temp. } \\
\left({ }^{\circ} \mathrm{C}\right)\left({ }^{\circ} \mathrm{F}\right)\end{array}$ & Riser No. & $\begin{array}{l}\text { Status of } \\
\operatorname{tanks}^{d}\end{array}$ \\
\hline BY-103 & 1510 & 66 & 1.6 & $\begin{array}{ll}26 & 79 \\
26^{\circ} & 80\end{array}$ & $\begin{array}{l}1 \\
5\end{array}$ & NS; AL \\
\hline BY-104 & 1540 & 83 & $3.3^{f}$ & $\begin{array}{ll}51^{e} & 123 \\
44 & 111\end{array}$ & $\begin{array}{c}1 \\
10 \mathrm{~B}\end{array}$ & IS; Sound \\
\hline BY-105 & 1900 & 36 & $4.9^{f}$ & $\begin{array}{ll}47 & 116 \\
44 & 112\end{array}$ & $\begin{array}{c}1 \\
10 \mathrm{C}\end{array}$ & NS; AL \\
\hline BY-106 & 2430 & 70 & $4.7^{f}$ & $51 \quad 123$ & 1 & NS; AL \\
\hline BY-107 & 1010 & 42 & 2.6 & $\begin{array}{ll}35 & 95 \\
37^{e} & 98\end{array}$ & $\begin{array}{l}1 \\
5\end{array}$ & IS; AL \\
\hline BY-108 & 863 & 58 & 2.7 & $\begin{array}{ll}42^{e} & 107 \\
41 & 106\end{array}$ & $\begin{array}{l}3 \\
8\end{array}$ & IS; AL \\
\hline BY -110 & 1510 & 71 & $3.3^{f}$ & $\begin{array}{ll}47 & 116 \\
41^{c} & 105\end{array}$ & $\begin{array}{c}1 \\
10 \mathrm{~A}\end{array}$ & IS; Sound \\
\hline $\mathrm{BY}-111$ & 1690 & 6 & $2.1^{f}$ & $\begin{array}{ll}31^{8} & 87 \\
28^{\circ} & 83\end{array}$ & $\begin{array}{c}1 \text { (LOW) } \\
14\end{array}$ & IS; Sound \\
\hline BY -112 & 1100 & 2 & $2.4^{f}$ & $\begin{array}{ll}32^{c} & 89 \\
28^{8} & 82\end{array}$ & $\frac{2}{15 \text { (LOW) }}$ & IS; Sound \\
\hline C-108 & 250 & 25 & $2.9^{f}$ & $\begin{array}{ll}23^{\mathbf{c}} & 74 \\
22 & 71\end{array}$ & $\begin{array}{l}1 \\
5\end{array}$ & IS; Sound \\
\hline C-109 & 250 & $6.8^{\mathrm{h}}$ & $3.0^{f}$ & $\begin{array}{ll}25^{\mathrm{e}} & 77 \\
25 & 76\end{array}$ & $\begin{array}{l}3 \\
8\end{array}$ & IS; Sound \\
\hline $\mathrm{C}-111$ & 216 & 33 & $2.5^{f}$ & $\begin{array}{ll}23 & 73 \\
22^{\mathrm{e}} & 71\end{array}$ & $\begin{array}{l}5 \\
6\end{array}$ & IS; AL \\
\hline$C-112$ & 394 & $11.5^{\mathrm{h}}$ & $3.3^{f}$ & $\begin{array}{ll}26 & 79 \\
26^{\circ} & 79\end{array}$ & $\begin{array}{l}1 \\
8\end{array}$ & IS; Sound \\
\hline $\mathrm{T}-107$ & 681 & 5 & $1.2^{f}$ & $\begin{array}{ll}17 & 63 \\
17^{\mathrm{e}} & 63\end{array}$ & $\begin{array}{l}4 \\
5\end{array}$ & NS; AL \\
\hline TX-118 & 1310 & $<3$ & 1.4 & $\begin{array}{ll}24^{e} & 75 \\
24 & 75\end{array}$ & $\begin{array}{l}1 \\
3\end{array}$ & IS; Sound \\
\hline TY-101 & 447 & 23 & $1.1^{f}$ & $\begin{array}{ll}18^{\circ} & 64 \\
17 & 63\end{array}$ & $\begin{array}{l}3 \\
4\end{array}$ & IS; AL \\
\hline
\end{tabular}


Table A-1. Summary of Contents and Status of Ferrocyanide Tanks."

\begin{tabular}{|c|c|c|c|c|c|c|}
\hline Tank & $\begin{array}{c}\text { Total waste } \\
\text { volume } \\
(1,000 \mathrm{~L})\end{array}$ & $\begin{array}{c}\mathrm{FeCN}^{\mathrm{b}} \\
(1,000 \mathrm{~g}-\mathrm{mol})\end{array}$ & $\begin{array}{l}\text { Heat load } \\
\qquad(\mathrm{kW})^{\mathrm{c}}\end{array}$ & $\begin{array}{l}\text { Maximum } \\
\text { temp. } \\
\left({ }^{\circ} \mathrm{C}\right)\left({ }^{\circ} \mathrm{F}\right)\end{array}$ & Riser No. & $\begin{array}{l}\text { Status of } \\
\tan k s^{d}\end{array}$ \\
\hline TY-103 & 613 & 28 & 1.5 & $\begin{array}{ll}20 & 68 \\
21^{:} & 69\end{array}$ & $\begin{array}{l}4 \\
7\end{array}$ & IS; AL \\
\hline TY-104 & 174 & 12 & 0.9 & $\begin{array}{ll}17^{\mathrm{e}} & 62 \\
17 & 62\end{array}$ & $\begin{array}{l}3 \\
4\end{array}$ & IS; AL \\
\hline
\end{tabular}

Notes:

- Reflects removal of four ferrocyanide tanks from the Watch List in July 1993 and two additional tanks in October 1994. Note: tanks 241-C-108, C-109, C-111, and C-112 were removed from the Watch List in June 1996 (Kinzer 1996).

Tank information as of June 1996; temperatures are the highest recorded during the quarter ending June 30, 1996.

- Original tank inventories (Borsheim and Simpson 1991).

c Heat load values from Table 7-1 in Crowe et al. (1993).

d IS - Interim-Stabilized Tank; NS - Not Stabilized; AL - Assumed Leaker Tank; Sound - Non-Leaking Tank.

- Readings from new instrument trees; tank 241-BY-105 already had two trees.

f New data taken from Crowe et al. 1995.

- Temperature reading from a single thermocouple in the LOW.

h Calculated as ferrocyanide $\left[\mathrm{Fe}(\mathrm{CN})_{6}^{-4}\right]$ based on the total cyanide values reported in Simpson et al. (1993a, 1993b). 
Table A-2. Ferrocyanide Tank Vapor Sampling Summary . (2 Sheets)

\begin{tabular}{|c|c|c|c|c|c|c|c|c|c|c|c|c|c|}
\hline Tank & $\begin{array}{c}\text { Date } \\
\text { Sampled } \\
\text { (Type) }\end{array}$ & $\begin{array}{l}\text { Flamm. } \\
(\% \text { LEL) }\end{array}$ & $\begin{array}{c}\text { Organic } \\
\text { Vapor } \\
(\text { ppmv) }\end{array}$ & $\begin{array}{c}\mathrm{NH}_{3} \\
(p p m v)^{d}\end{array}$ & $\begin{array}{c}\mathrm{NH}_{3} \\
\text { (ppmv) }\end{array}$ & $\begin{array}{c}\text { HCN } \\
(\text { ppmv })^{d}\end{array}$ & $\begin{array}{l}\mathrm{NO}+\mathrm{NO}_{2} \\
(\mathrm{ppmv})^{d, 6}\end{array}$ & $\begin{array}{l}\text { TNMOC } \\
\left(\mathrm{mg} / \mathrm{m}^{3}\right)^{f}\end{array}$ & $\begin{array}{c}\mathrm{H}_{2} \\
(\mathrm{ppmv})^{\mathrm{s}}\end{array}$ & $\begin{array}{c}\mathrm{N}_{2} \mathrm{O} \\
(\text { ppmv) }\end{array}$ & $\begin{array}{c}\mathrm{CO} \\
(\text { ppmv) }\end{array}$ & $\begin{array}{c}\mathrm{CO}_{2} \\
(\operatorname{ppmv})^{\mathrm{r}}\end{array}$ & $\begin{array}{c}\text { Water } \\
\text { Content } \\
\% \mathrm{RH}\left({ }^{\circ} \mathrm{C}\right)^{\mathrm{h}}\end{array}$ \\
\hline$\overline{\mathrm{B} Y}-103$ & $\begin{array}{l}05 / 05 / 94(2) \\
11 / 01 / 94(3)\end{array}$ & $\begin{array}{r}<1 \\
-j\end{array}$ & $\begin{array}{l}1.2 \\
--\end{array}$ & $\begin{array}{l}25 \\
-\end{array}$ & $\begin{array}{l}30.7 \\
26\end{array}$ & $\begin{array}{c}<0.005 \\
-\end{array}$ & $\begin{array}{l}<0.3 \\
<0.2\end{array}$ & $\begin{array}{l}5.2 \\
--\end{array}$ & $\begin{aligned} & 21.4 \\
< & 99\end{aligned}$ & $\begin{array}{l}49.2 \\
16.5\end{array}$ & $\begin{array}{l}<1 \\
<12\end{array}$ & 126 & $49\left(25.5^{\circ} \mathrm{C}\right)$ \\
\hline BY-104 & $\begin{array}{l}04 / 22 / 94(2) \\
06 / 24 / 94(3)\end{array}$ & $\begin{array}{r}<1 \\
--\end{array}$ & $\begin{array}{l}26 \\
--\end{array}$ & $\begin{array}{r}200 \\
--\end{array}$ & $\begin{array}{l}285 \\
248\end{array}$ & $\begin{array}{c}<0.005^{i} \\
--\end{array}$ & $\begin{array}{l}<0.3 \\
<0.4\end{array}$ & $\begin{array}{l}56 \\
61\end{array}$ & $\begin{array}{l}204 \\
295\end{array}$ & $\begin{array}{l}305 \\
201\end{array}$ & $\begin{array}{r}<1 \\
1\end{array}$ & $\overline{10.5}$ & $58\left(26^{\circ} \mathrm{C}\right)$ \\
\hline BY-105 & $\begin{array}{l}05 / 09 / 94(2) \\
07 / 07 / 94 \text { (3) }\end{array}$ & $\begin{array}{r}<1 \\
-.\end{array}$ & $\begin{array}{l}4.9 \\
--\end{array}$ & $\begin{array}{l}40 \\
-\end{array}$ & $\begin{array}{l}57 \\
43\end{array}$ & $\begin{array}{c}<0.005^{i} \\
--\end{array}$ & $\begin{array}{l}<0.1 \\
<0.2\end{array}$ & $\begin{array}{l}17.8 \\
12.7\end{array}$ & $\begin{array}{l}85 \\
48\end{array}$ & $\begin{array}{r}122 \\
50\end{array}$ & $\begin{array}{l}0.5 \\
0.4\end{array}$ & $\overline{94}$ & $61\left(26^{\circ} \mathrm{C}\right)$ \\
\hline$\overline{B Y}-106$ & $\begin{array}{l}05 / 04 / 94(2) \\
07 / 08 / 94(3)\end{array}$ & $\begin{array}{r}<1 \\
--\end{array}$ & $\begin{array}{l}5.7 \\
-\end{array}$ & $\begin{array}{l}60 \\
-\end{array}$ & $\begin{array}{l}87 \\
74\end{array}$ & $<0.01--$ & $\begin{array}{l}<0.2 \\
<0.2\end{array}$ & $\begin{array}{l}6.3 \\
9.9\end{array}$ & $\begin{array}{l}46 \\
46\end{array}$ & $\begin{array}{l}94 \\
71\end{array}$ & $\overline{0 .}$ & $\overline{47.6}$ & $57\left(27^{\circ} \mathrm{C}\right)$ \\
\hline$\overline{B Y-107}$ & $\begin{array}{l}03 / 25 / 94(2) \\
10 / 26 / 94(3)\end{array}$ & $\begin{array}{c}3-4 \\
--\end{array}$ & $\begin{array}{r}67 \\
--\end{array}$ & $\begin{array}{r}97 \\
-\end{array}$ & 972 & - & $<\overline{0.2}$ & $\begin{array}{l}173 \\
150\end{array}$ & $\begin{array}{l}692 \\
267\end{array}$ & $\begin{array}{l}802 \\
621\end{array}$ & $\begin{array}{r}<5 \\
<20\end{array}$ & $\overline{94}$ & $36\left(33.1^{\circ} \mathrm{C}\right)$ \\
\hline$\overline{B Y}-108$ & $\begin{array}{l}03 / 28 / 94(2) \\
10 / 27 / 94(3)\end{array}$ & $\begin{array}{c}1 \\
-\end{array}$ & $\begin{array}{l}97 \\
\ldots\end{array}$ & $\begin{array}{r}700 \\
+\end{array}$ & $104 \overline{0}$ & $\begin{array}{l}- \\
--\end{array}$ & $\begin{array}{l}<0.5 \\
<0.1\end{array}$ & $\begin{array}{l}594 \\
510\end{array}$ & $\begin{array}{l}644 \\
400\end{array}$ & $\begin{array}{l}757 \\
641\end{array}$ & $\begin{array}{r}<5 \\
<76\end{array}$ & $\overline{224}$ & $56\left(25.7^{\circ} \mathrm{C}\right)$ \\
\hline$\overline{\mathrm{B} Y}-110$ & $\begin{array}{l}09 / 27 / 92(1) \\
11 / 11 / 94(3)\end{array}$ & $\begin{array}{r}<1 \\
--\end{array}$ & $\begin{array}{r}350 \\
-\end{array}$ & $\begin{array}{r}612 \\
-\end{array}$ & 401 & $\begin{array}{l}<2 \\
--\end{array}$ & $\begin{array}{l}<0.5 \\
<0.2\end{array}$ & $\overline{29}$ & $<16 \overline{0}$ & 103 & $<\overline{76}$ & 229 & $31\left(27^{\circ} \mathrm{C}\right)$ \\
\hline BY-111 & $\begin{array}{l}05 / 11 / 94(2) \\
11 / 16 / 94(3)\end{array}$ & $\begin{array}{r}<1 \\
--\end{array}$ & $\begin{array}{l}8.9 \\
\ldots\end{array}$ & $\begin{array}{r}60 \\
-\end{array}$ & 59 & $\begin{array}{l}- \\
-\end{array}$ & $<\overline{0.2}$ & 9.6 & 67 & $\overline{99}$ & $\begin{array}{l}<1 \\
<1\end{array}$ & 219 & $27\left(27^{\circ} \mathrm{C}\right)$ \\
\hline BY-112 & $\begin{array}{l}03 / 26 / 93(1) \\
11 / 18 / 94(3)\end{array}$ & $\begin{array}{r}<1 \\
--\end{array}$ & $\begin{array}{l}5.9 \\
--\end{array}$ & $\begin{array}{r}10 \\
--\end{array}$ & 63 & $\begin{array}{l}<2 \\
--\end{array}$ & $\begin{array}{l}<0.5 \\
<0.2\end{array}$ & $\overline{5.8}$ & $<94$ & 40 & $<\overline{12}$ & $\overline{-}$ & $53\left(23.3^{\circ} \mathrm{C}\right)$ \\
\hline C-108 & $\begin{array}{c}07 / 23 / 93(* *) \\
07 / 07 / 94(2) \\
08 / 05 / 94(3)\end{array}$ & $\begin{array}{r}<1 \\
-- \\
--\end{array}$ & $\begin{array}{l}1.2 \\
-- \\
-\end{array}$ & $\begin{array}{r}<2 \\
- \\
-\end{array}$ & $\begin{array}{l}-- \\
- \\
2.7\end{array}$ & $\begin{array}{c}<2 \\
<0.0002^{i} \\
--\end{array}$ & $\begin{array}{c}<0.5 \\
-- \\
<0.3\end{array}$ & $\begin{array}{l}\quad \ddot{0} \\
<0.4 \\
<1.4\end{array}$ & $\begin{array}{c}- \\
- \\
15.3\end{array}$ & $\begin{array}{r}- \\
- \\
344\end{array}$ & $\begin{array}{l}1 \\
- \\
0.1\end{array}$ & $\begin{array}{l}- \\
- \\
16.3\end{array}$ & $\begin{array}{c}- \\
- \\
76,\left(25^{\circ} \mathrm{C}\right)\end{array}$ \\
\hline C-109 & $\begin{array}{l}06 / 23 / 94(2) \\
08 / 09 / 94(3)\end{array}$ & $\begin{array}{r}<1 \\
--\end{array}$ & $\begin{array}{c}1 \\
--\end{array}$ & $\begin{array}{r}4 \\
-\end{array}$ & $\overline{10.1}$ & $\begin{array}{l}- \\
--\end{array}$ & $<0.6$ & $\begin{array}{l}- \\
0.65\end{array}$ & $12 \overline{5}$ & 369 & $\overline{0.4}$ & $\overline{3}$ & $79\left(27^{\circ} \mathrm{C}\right)$ \\
\hline C-111 & $\begin{array}{c}08 / 10 / 93(* *) \\
06 / 20 / 94(2) \\
09 / 13 / 94(3)\end{array}$ & $\begin{array}{l}<1 \\
<1 \\
-\end{array}$ & $\begin{array}{c}<0.2 \\
<0.2 \\
--\end{array}$ & $\begin{array}{r}<2 \\
<2 \\
-\end{array}$ & $\begin{array}{l}- \\
0.1 \\
5.6\end{array}$ & $\begin{array}{c}<0.04^{\mathrm{k}} \\
<0.01^{1} \\
--\end{array}$ & $\begin{array}{l}<0.5 \\
<0.2 \\
\leq 0.7\end{array}$ & $\begin{array}{c}<0.3 \\
0.18 \\
<0.6\end{array}$ & $\begin{array}{c}16 \\
12.4\end{array}$ & 99 & $\begin{array}{l}0.1 \\
- \\
0.1\end{array}$ & $\begin{array}{r}-- \\
- \\
198\end{array}$ & $\begin{array}{c}\overline{-} \\
\overline{-} \\
86\left(27^{\circ} \mathrm{C}\right)\end{array}$ \\
\hline C-112 & $\begin{array}{l}06 / 24 / 94(2) \\
08 / 11 / 94(3)\end{array}$ & $\begin{array}{r}<1 \\
--\end{array}$ & $\begin{array}{c}<0.2 \\
--\end{array}$ & $\begin{array}{l}4 \\
-\end{array}$ & $\overline{22.7}$ & $\begin{array}{l}-- \\
--\end{array}$ & $\begin{array}{c}-- \\
<0.7\end{array}$ & $\overline{3.4}$ & $\begin{array}{r}-- \\
204\end{array}$ & $54 \overline{4}$ & $\overline{0.9}$ & $\overline{102}$ & $82\left(28^{\circ} \mathrm{C}\right)$ \\
\hline $\mathrm{T}-107$ & $\begin{array}{l}10 / 22 / 92(1) \\
01 / 18 / 95(3)\end{array}$ & $\begin{array}{r}<1 \\
\cdots\end{array}$ & $\begin{array}{l}24 \\
--\end{array}$ & $\begin{array}{r}203 \\
--\end{array}$ & $12 \overline{125}$ & $\begin{array}{l}<2 \\
--\end{array}$ & $\begin{array}{l}<0.5 \\
<0.1\end{array}$ & $\ddot{1.4}$ & $\begin{array}{r}<\ddot{9} \\
\end{array}$ & $4 \overline{42}$ & $<\overline{12}$ & $\overline{75}$ & $82\left(17.2^{\circ} \mathrm{C}\right)$ \\
\hline
\end{tabular}


Table A-2. Ferrocyanide Tank Vapor Sampling Summary . (2 Sheets)

\begin{tabular}{|c|c|c|c|c|c|c|c|c|c|c|c|c|c|}
\hline Tank & $\begin{array}{c}\text { Date } \\
\text { Sampled } \\
\text { (Type) }\end{array}$ & $\begin{array}{l}\text { Flamm. } \\
(\% \text { LEL) }\end{array}$ & $\begin{array}{c}\text { Organic } \\
\text { Vapor } \\
\text { (ppmv) }\end{array}$ & $\begin{array}{c}\mathrm{NH}_{3} \\
(\text { ppmv) }\end{array}$ & $\begin{array}{c}\mathrm{NH}_{3} \\
(\text { ppmv) }\end{array}$ & $\begin{array}{c}\text { HCN } \\
(\text { ppmv) }\end{array}$ & $\begin{array}{l}\mathrm{NO}+\mathrm{NO}_{2} \\
(\text { ppmv) }\end{array}$ & $\begin{array}{l}\text { TNMOC } \\
\left(\mathrm{mg} / \mathrm{m}^{3}\right)^{f}\end{array}$ & $\begin{array}{c}\mathrm{H}_{2} \\
(\operatorname{ppmv})^{\mathrm{s}}\end{array}$ & $\begin{array}{c}\mathrm{N}_{2} \mathrm{O} \\
(\text { ppmv) }\end{array}$ & $\begin{array}{c}\mathrm{CO} \\
(\mathrm{ppmv})^{\ell}\end{array}$ & $\begin{array}{c}\mathrm{CO}_{2} \\
(\text { ppmv })^{\mathrm{s}}\end{array}$ & $\begin{array}{c}\text { Water } \\
\text { Content } \\
\text { \%RH }\left({ }^{\circ} \mathrm{C}\right)^{\mathrm{h}}\end{array}$ \\
\hline TX-118 & $\begin{array}{l}07 / 28 / 93(* *) \\
09 / 07 / 94(2) \\
12 / 16 / 94(3)\end{array}$ & $\begin{array}{r}<1 \\
<1 \\
--\end{array}$ & $\begin{array}{l}0.3 \\
7.8 \\
--\end{array}$ & $\begin{array}{r}10 \\
28 \\
\ldots\end{array}$ & $\overline{--}$ & $\begin{array}{c}<2 \\
<0.02 \\
-\end{array}$ & $\begin{array}{c}<0.5 \\
<0.5 \\
--\end{array}$ & $\begin{array}{l}-\overline{9.3} \\
-\end{array}$ & $\begin{array}{r}-\overline{97} \\
<94\end{array}$ & $\begin{array}{l}-- \\
17 \\
29\end{array}$ & $\begin{array}{r}-\overline{2.5} \\
<12\end{array}$ & $\begin{array}{l}-- \\
54 \\
98\end{array}$ & $42\left(21.5^{\circ} \mathrm{C}\right)$ \\
\hline TY-101 & $\begin{array}{l}08 / 04 / 94(2) \\
04 / 06 / 95 \text { (3) }\end{array}$ & $\begin{array}{r}<1 \\
--\end{array}$ & $\begin{array}{r}4 \\
--\end{array}$ & $\begin{array}{l}12 \\
--\end{array}$ & $\begin{array}{l}16 \\
16\end{array}$ & $\begin{array}{c}<0.01 \\
-\end{array}$ & $\begin{array}{l}<0.2 \\
<0.2\end{array}$ & 1.0 & $<\overline{93}$ & $\overline{98}$ & $<\overline{12}$ & $\overline{83}$ & $77\left(15.6^{\circ} \mathrm{C}\right)$ \\
\hline TY-103 & $\begin{array}{l}08 / 04 / 94(2) \\
04 / 11 / 95(3)\end{array}$ & $\begin{array}{r}<1 \\
-- \\
\end{array}$ & $\begin{array}{l}5 \\
--\end{array}$ & $\begin{array}{l}30 \\
.- \\
\end{array}$ & $\begin{array}{l}31 \\
49\end{array}$ & $\begin{array}{c}<0.01 \\
-\end{array}$ & $\begin{array}{l}<0.1 \\
<0.2 \\
\end{array}$ & 60 & $<--$ & $\begin{array}{r}-- \\
159\end{array}$ & $\begin{array}{r}- \\
<12\end{array}$ & $\overline{121}$ & $85\left(15.9^{\circ} \mathrm{C}\right)$ \\
\hline TY-104 & $\begin{array}{l}08 / 05 / 94(2) \\
04 / 27 / 95(3)\end{array}$ & $\begin{array}{r}<1 \\
--\end{array}$ & $\begin{array}{l}2.5 \\
--\end{array}$ & $\begin{array}{r}24 \\
-\end{array}$ & $\begin{array}{l}50 \\
61\end{array}$ & - & $\begin{array}{l}<0.2 \\
\leq 0.2\end{array}$ & $\overline{3}$ & $<49$ & 98 & $<23$ & $<23$ & $88\left(15.6^{\circ} \mathrm{C}\right)$ \\
\hline
\end{tabular}

Sample Type:

**Vapor samples taken from in-tank, non-heated tubes using a vapor sampling cart (SUMMA ${ }^{\mathrm{TM}}$ only - no $\mathrm{NH}_{3}$ ).

1 Monitoring performed by Industrial Hygiene technicians using three varying length, non-heated sampling tubes into the tank headspace to evaluate for flammability and toxic vapors; this method is no longer used.

2 In Situ Sampling (ISS) - Sampling is performed by lowering special sorbent traps into the tank headspace that are connected topside to a portable handcart.

3 Sampling involves the mobile vapor sampling system, heated transfer lines, and installation of a water-heated sampling probe into the tank headspace. All ferrocyanide tanks are scheduled for resampling using this method.

beasured using a combustible gas meter; LEL = Lower Explosive Limit.

- Measured using an Organic Vapor Monitor (OVM). OVM readings are affected by ammonia; OVM ammonia response is approximately 13:1, so that

$13 \mathrm{ppmv}$ of ammonia is indicated as $1 \mathrm{ppmv}$ of organic vapors $(\mathrm{p} / \mathrm{M}(\mathrm{vol})=$ parts per million by volume).

For Type 1 sampling only; value is measured using colorimetric (Dräger ${ }^{\mathrm{MM}}$ ) tubes (values are estimated, and not quantitative).

- Analyses of ammonia sorbent trap samples.

I Total non-methane organic compound (TNMOC) concentrations measured for SUMMA ${ }^{\mathrm{TM}}$ canister samples.

- Analyses of SUMMA ${ }^{\text {TM }}$ canister samples from Type **, and 3 sampling methods.

I\% RH is the percent relative humidity calculated from measured headspace water content $(\mathrm{mg} / \mathrm{L})$, temperature and atmospheric pressure. Temperature of headspace gas in ${ }^{\circ} \mathrm{C}$ is listed in parentheses.

i HCN determinations obtained in selected tanks using a special sorbent trap; values shown are below detection limit of the measurement technique.

i -- Data not yet available or not obtained by this type of sampling.

k This HCN number was < 0.04 parts per billion vapor as determined by a special sodjum hydroxide bubbler. 


\section{APPENDIX REFERENCES}

Borsheim, G. L., and B. C. Simpson, 1991, An Assessment of the Inventories of Ferrocyanide Watch List Tanks, WHC-SD-WM-EP-133, Rev. 0, Westinghouse Hanford Company, Richland, Washington.

Crowe, R. D., M. Kummerer, and A. K. Postma, 1993, Estimation of Heat Load in Waste Tanks Using Average Vapor Space Temperatures, WHC-EP-0709, Rev. 0, Westinghouse Hanford Company, Richland, Washington.

Crowe, R. D., D. P. Maassen, and S. A. Parra, 1995, Calculated Heat Load for Watchlist Single-Shell Waste Tanks Using the Average Vapor Space Temperatures, (letter report attached to internal memorandum from H. Toffer to R. J. Cash, September 29), Westinghouse Hanford Company, Richland, Washington.

Kinzer, J. E., 1996, Authorization to Remove Four Ferrocyanide Tanks, 241-C-108, 241-C-109, 241-C-111, and 241-C-112 from the Watch List, (letter 9601578B/ 96-WSD-116 to A. L. Trego, President, Westinghouse Hanford Company, June 25), U.S. Department of Energy, Richland Operations Office, Richland, Washington.

Simpson, B. C., G. L. Borsheim, and L. Jensen, 1993a, Tank Characterization Report: Tank 241-C-109, WHC-EP-0688, Westinghouse Hanford Company, Richland, Washington.

Simpson, B. C., G. L. Borsheim, and L. Jensen, 1993b, Tank Characterization Data Report: Tank 241-C-112, WHC-EP-0640, Rev. 1, Westinghouse Hanford Company, Richland, Washington. 
This page intentionally left blank. 


\section{DISTRIBUTION}

Number of copies

\section{OFFSITE}

6

U.S. Department of Energy

EM-38, Trevion II

12800 Middlebrook Road

Germantown, MD 20874

Harry Calley (4)

Maureen Hunemuller

Ken Lang

2

U.S. Department of Energy

Forrestal Building

1000 Independence Avenue SW

Washington, DC 20585

Shirley Campbell, EH-71

John Kaysak, EM-25

1

Charles S. Abrams

1987 Virginia

Idaho Falls, ID 83404

1

David O. Campbell

102 Windham Road

Oak Ridge, TN 37830

1

Fred N. Carlson 6965 North 5 th West

Idaho Falls, ID 83401

1

Billy C. Hudson

202 Northridge Court

Lindsborg, KA 67456

1

Thomas S. Kress

102-B Newridge Road

Oak Ridge, TN 37839 
DISTRIBUTION (Continued)

Number of copies

\section{OFFSITE}

1

Thomas E. Larson

2711 Walnut Street

Los Alamos, NM 87544

Air Products \& Chemicals, Inc. 7201 Hamilton Blvd

Allentown, PA 18195-1501

George E. Schmauch

1

Brookhaven National Laboratory

Upton, NY 11973

Kamal K. Bandyopadhyay

2

Fauske and Associates, Inc. 16W070 W. 83rd St.

Burr Ridge, IL 60521

Michael Epstein

Hans K. Fauske

1

G \& P Consulting, Inc. 3640 Ballard Road

Dallas, OR 97338

Arlin K. Postma

1

Hanvard University

295 Upland Avenue

Newton Highlands, MA 02161

Melvin W. First 


\section{DISTRIBUTION (Continued)}

Number of copies

\section{OFFSITE}

1

1

1

1

1

1
Los Alamos National Laboratory

P.O. Box 1663

Los Alamos, NM 87545

Steve F. Agnew

MTT/Department of Nuclear Engineering

77 Massachusetts Ave.

Room 24-102

Cambridge, MA 02139

Mujid S. Kazimi

Nuclear Consulting Services, Inc.

P.O. Box 29151

Columbus, $\mathrm{OH}$ 43229-0151

J. Louis Kovach

Qak Ridge National Laboratory

Emory D. Collins

P.O. Box 2008

7930, MS-6385

Oak Ridge, TN 37831-6385

Charles W. Forsberg

P.O. Box 2008

MS-6495

Oak Ridge, TN 37831-6495

Rice University

5211 Paisley

Houston, TX 77096

Andrew S. Veletsos 


\section{DISTRIBUTION (Continued)}

\section{Number of copies}

\section{OFFSITE}

2

3

1

1

1
Sandia National Laboratories

P.O. Box 5800

Albuquerque, NM 87185

Dana A. Powers, MS-0744

Scott E. Slezak, MS-0741

Science Applications Intemational Corporation 20300 Century Blvd, Suite 200-B

Germantown, MD 20874

Paul Hogroian (3)

State of Washington - Department of Ecology

Robert C. King

P. O. Box 47600

Olympia, WA $98504-7600$

Alex B. Stone

1315 W. 4th Avenue

Kennewick, WA 99336

Waste Policy Institute

555 Quince Orchard Road, Suite 600

Gaitherburg, MD 20878-1437

Donald T. Oakley 


\section{DISTRIBUTION (Continued)}

\section{ONSITE}

9

\section{U.S. Department of Energy. Richland Operations Office}

W. F. Hendrickson (2)

S7-54

D. H. Irby S7-54

A. G. Krasopoulos

A4-81

J. K. McClusky

S7-50

J. C. Peschong

S7-53

Public Reading Room

H2-53

RL Docket File (2)

B1-17

4

Pacific Northwest Laboratory

J. W. Brothers

K5-22

R. T. Hallen

P8-38

M. A. Lilga

P8-38

Hanford.Technical Library

P8-55

Westinghouse Hanford Company

H. Babad

S7-30

J. B. Billetdeaux

S7-15

R. J. Cash (2)

S7-14

M. D. Crippen

I5-31

R. D. Crowe

HO-38

M. L. Dexter

R1-51

D. R. Dickinson

L5-31

G. T. Dukelow (2)

S7-14

S. J. Eberlein

R2-12

J. M. Grigsby

A3-37

M. N. Islam

R3-08

D. W. Jeppson

L5-31

N. W. Kirch

R2-11

C. A. Kuhlman

B3-30 


\section{DISTRIBUTION (Continued)}

Westinghouse Hanford Company (Continued)

J. E. Meacham (2) S7-14

N. J. Milliken H4-65

S. R. Moreno B3-06

F. R. Reich L5-55

B. C. Simpson R2-12

Central Files A3-88

Correspondence Processing A3-01

EDMC H6-08

DPC A3-94 